\title{
Anatomical Organization of Urocortin 3-Synthesizing Neurons and Immunoreactive Terminals in the Central Nervous System of Non-Human Primates [Sapajus spp.]
}

Daniella S. Battagello ${ }^{1,2}$, Giovanne B. Diniz ${ }^{1}$, Paulo L. Candido ${ }^{1,3}$, Joelcimar M. da Silva ${ }^{1}$, Amanda R. de Oliveira ${ }^{1}$, Kelly R. Torres da Silva ${ }^{1,4}$, Claudimara F. P. Lotfi ${ }^{5}$, José A. de Oliveira ${ }^{4}$, Luciane V. Sita ${ }^{1}$, Cláudio A. Casatti ${ }^{4,6}$, David A. Lovejoy ${ }^{7}$ and Jackson C. Bittencourt ${ }^{1,2 *}$

${ }^{1}$ Department of Anatomy, Institute of Biomedical Sciences, University of São Paulo, São Paulo, Brazil, ${ }^{2}$ Center for Neuroscience and Behaviour, Institute of Psychology, University of São Paulo, São Paulo, Brazil, ${ }^{3}$ Department of Anatomy, Santa Marcelina Medical School, São Paulo, Brazil, ${ }^{4}$ Department of Basic Sciences, São Paulo State University, UNESP, Araçatuba, São Paulo, Brazil, ${ }^{5}$ Laboratory of Cellular Structure and Function, Department of Anatomy, Institute of Biomedical Sciences, University of São Paulo, São Paulo, Brazil, ${ }^{6}$ Institute of Biosciences, UNESP-São Paulo State University, Botucatu, Brazil, 'Laboratory of Neuroendocrinology, Department of Cell and Systems Biology, University of Toronto, Toronto, ON, Canada

\section{OPEN ACCESS}

Edited by: Jose L. Lanciego, Universidad de Navarra, Spain

Reviewed by: Andrew L. Gundlach, Florey Institute of Neuroscience and Mental Health, Australia Henry J. Waldvogel, University of Auckland, New Zealand

Tomas Gonzalez-Hernandez, Universidad de La Laguna, Spain

*Correspondence: Jackson C. Bittencourt jcbitten@icb.usp.br

Received: 12 April 2017 Accepted: 26 June 2017 Published: 24 July 2017

Citation: Battagello DS, Diniz GB, Candido PL, da Silva JM, de Oliveira AR, Torres da Silva KR, Lotfi CFP, de Oliveira JA,

Sita LV, Casatti CA, Lovejoy DA and Bittencourt JC (2017) Anatomical Organization of Urocortin

3-Synthesizing Neurons and Immunoreactive Terminals in the

Central Nervous System of Non-Human Primates [Sapajus spp.] Front. Neuroanat. 11:57. doi: 10.3389/fnana.2017.00057
Urocortin 3 (UCN3) is a neuropeptide member of the corticotropin-releasing factor (CRF) peptide family that acts as a selective endogenous ligand for the CRF, subtype $2\left(\mathrm{CRF}_{2}\right)$ receptor. Immunohistochemistry and in situ hybridization data from rodents revealed UCN3-containing neurons in discrete regions of the central nervous system (CNS), such as the medial preoptic nucleus, the rostral perifornical area (PFA), the medial nucleus of the amygdala and the superior paraolivary nucleus. UCN3-immunoreactive (UCN3-ir) terminals are distributed throughout regions that mostly overlap with regions of $\mathrm{CRF}_{2}$ messenger RNA (mRNA) expression. Currently, no similar mapping exists for non-human primates. To better understand the role of this neuropeptide, we aimed to study the UCN3 distribution in the brains of New World monkeys of the Sapajus genus. To this end, we analyzed the gene and peptide sequences in these animals and performed immunohistochemistry and in situ hybridization to identify UCN3 synthesis sites and to determine the distribution of UCN3-ir terminals. The sequencing of the Sapajus spp. UCN3-coding gene revealed $88 \%$ and $65 \%$ identity to the human and rat counterparts, respectively. Additionally, using a probe generated from monkey cDNA and an antiserum raised against human UCN3, we found that labeled cells are mainly located in the hypothalamic and limbic regions. UCN3-ir axons and terminals are primarily distributed in the ventromedial hypothalamic nucleus $(\mathrm{VMH})$ and the lateral septal nucleus (LS). Our results demonstrate that UCN3-producing neurons in the CNS of monkeys are phylogenetically conserved compared to those of the rodent brain, that the distribution of fibers agrees with the distribution of $\mathrm{CRF}_{2}$ in other primates and that there is anatomical evidence for the participation of UCN3 in neuroendocrine control in primates.

Keywords: autonomic nervous system, corticotropin-releasing factor, monkey brain, paraventricular nucleus of the hypothalamus, corticotropin-releasing factor receptors, stress response 


\section{INTRODUCTION}

Since the discovery of corticotropin-releasing factor (CRF) in the ovine hypophysis by Vale et al. (1981), several groups conducted studies in an attempt to find homologs sequences in other species. This culminated in the identification of other members that have structural and functional homology to CRF: Urocortin 1 (UCN1), discovered by Vaughan et al. (1995), Urocortin 2 (UCN2), described by Reyes et al. (2001) and Urocortin 3 (UCN3), reported by Lewis et al. (2001). In the present study, we will follow the suggested nomenclature for CRF receptors, CRF, subtype $1\left(\mathrm{CRF}_{1}\right)$ and $\mathrm{CRF}$, subtype $2\left(\mathrm{CRF}_{2}\right)$, and their ligands, that was proposed by Hauger et al. (2003). UCN3, the newest member of the CRF family of peptides, is a 38 -amino acid (aa) neuropeptide

Abbreviations: $3 \mathrm{~V}, 3$ rd ventricle; aa, amino acids; ac, anterior commissure; acp, anterior commissure, posterior limb; AA, anterior amygdaloid area; $\mathrm{AH}$, anterior hypothalamic area; AHiPC, amygdalohippocampal area, parvicellular part; AL, anterior lobe of the hypophysis; AMPO, anteromedial preoptic nucleus; Arc, arcuate hypothalamic nucleus; ARH, rat arcuate nucleus; BM, basomedial amygdaloid nucleus; BMMC, basomedial amygdaloid nucleus, magnocellular part; BST, rat bed nucleus of the stria terminalis; BSTp, rat posterior part of BST; CA4, field CA4 of the hippocampus; Cd, caudate nucleus; Ce, central nucleus of the amygdala; $\mathrm{CeI}$, dorsal motor nucleus of vagus, centrointermediate part; CeM, central amygdaloid nucleus, medial division; Co, cortical nucleus of the amygdala; $\mathrm{CM}$, central medial thalamic nucleus; CL, centrolateral thalamic nucleus; $\mathrm{CRF}$, corticotropin-releasing factor; $\mathrm{CRF}_{1}$, corticotropin-releasing factor receptor, subtype $1 ; \mathrm{CRF}_{2}$, corticotropin-releasing factor receptor, subtype 2; DAB, 3,3'-Diaminobenzidine; f, fornix; GrDG, granule cell layer of the dentate gyrus; hnt, hypothalamo-neurohypophysial tract; HFD, high-fat diet; ic, internal capsule; icv, intracerebroventricular; ip, intraperitoneal injection; JPLH, juxtaparaventricular part of lateral hypothalamus; ko/UCN3, "knockout" UCN3; LH, lateral hypothalamic area; LHb, lateral habenular nucleus; LPAG, lateral periaqueductal gray; LPO, lateral preoptic nucleus; LS, lateral septal nucleus; LSI, LS, intermediate part; LSV, LS, ventral part; LTN, lateral tuberal nucleus; LV, lateral ventricle; Me, medial amygdaloid nucleus; MeA, rat medial amygdaloid nucleus; ME, median eminence; MePO, rat median preoptic nucleus; $\mathrm{MHb}$, medial habenular nucleus; MnPO, median preoptic nucleus; MPA, medial preoptic area; MPO, medial preoptic nucleus; MS, medial septal nucleus; NAS, nickel ammonium sulfate; Sol, solitary nucleus; opt, optic tract; $\mathrm{Pa}$, monkey paraventricular nucleus of the hypothalamus; PaMD, paraventricular hypothalamic nucleus, magnocellular part, dorsal division; PaPD, paraventricular hypothalamic nucleus, parvicellular part, dorsal division; PaPV, paraventricular hypothalamic nucleus, parvicellular part, ventral division; PC, paracentral thalamic nucleus; Pe, periventricular hypothalamic nucleus; PeF, perifornical nucleus; $\mathrm{PH}$, rat posterior hypothalamic area; PI, pars intermedia of the hypophysis; PL, posterior lobe of the hypophysis; ppUCN3, prepro-UCN3; PVH, rat paraventricular nucleus of the hypothalamus; PVHap, anterior parvicellular part of the paraventricular nucleus of the hypothalamus; rCRF, rat CRF; rUCN3, rat UCN3; SCP, stresscopin; SFi, septofimbrial nucleus; SO, supraoptic nucleus; sox, supraoptic decussation; Sp5C, spinal trigeminal nucleus, caudal part; ST, bed nucleus of stria terminalis; STLD, ST, lateral division, dorsal part; STMA, ST, medial division, anterior part; STMV, ST, medial division, ventral part; TRH, thyrotropin-releasing hormone; TSH, thyroid stimulating hormone; UCN1, Urocortin 1; UCN2, Urocortin 2; UCN3, Urocortin 3; UCN3-ir, Urocortin 3 immunoreactivity; VGLUT2, second conveyor vesicular glutamate; VLPAG, periaqueductal gray matter, ventrolateral part; VMH, ventromedial hypothalamic nucleus; VMHDM, dorsomedial part of VMH; VMHVL, ventrolateral part of VMH; $w t / U C N 3$, wild-type UCN3. initially described and characterized in humans and rodents (Hsu and Hsueh, 2001; Lewis et al., 2001). This peptide was also described by Hsu and Hsueh (2001) and became known as Stresscopin (SCP). Analysis of residue or nucleotide sequences of $\mathrm{UCN} 2$ and UCN3 seems to indicate that these two neuropeptides are more related to each other than to other members of the "CRF family" (Lewis et al., 2001). Pharmacological studies demonstrate that both human and murine UCN3 bind to mouse $\mathrm{CRF}_{2}$ with high affinity but do not bind to murine $\mathrm{CRF}_{1}$ (Hsu and Hsueh, 2001; Lewis et al., 2001). This finding indicates a possible role of $\mathrm{UCN} 3$ as an endogenous ligand for the $\mathrm{CRF}_{2}$ receptor and that it has functional implications, such as the neuroendocrine control of food intake.

In rodents, messenger RNA (mRNA) encoding the UCN3 precursor molecule (ppUCN3) was detected in several peripheral organs and a few cortical and subcortical areas (e.g., the hypothalamus, amygdaloid complex and brainstem nuclei; Hsu and Hsueh, 2001; Lewis et al., 2001; Kang et al., 2007). This distribution is dissimilar to what has been reported for CRF (Swanson et al., 1983), UCN1 (Vaughan et al., 1995; Bittencourt et al., 1999) and UCN2 (Reyes et al., 2001). In the central nervous system (CNS) of rodents, UCN3 is found in the median preoptic nucleus (MnPO), the rostral perifornical area (PFA) that encompasses areas just lateral to the paraventricular nucleus $(\mathrm{PVH})$, the posterior part of the bed nucleus of stria terminalis (BSTp) and the medial amygdaloid nucleus (MeA; Lewis et al., 2001).

The non-human primates Sapajus libidinosus and Sapajus nigritus (Sapajus spp.) are sympatric in some areas of South America and were previously designated Cebus apella. They belong to the New World monkeys, and they are among the Neotropical primate species that are commonly used for biomedical research (Silva, 2001; Fragaszy et al., 2004; Alfaro et al., 2012; Izar et al., 2012; Lynch Alfaro et al., 2012). Because the organization of the nervous system in these species is highly conserved across and within the vertebrate taxa, their brains are largely similar to other primates (Fragaszy et al., 2004).

Data regarding the distribution of UCN3 immunoreactive (UCN3-ir) cell bodies, fibers and terminals, and UCN3 mRNA expression are non-existent for primates. Also, Sapajus spp. is a suitable primate model for comparison with other mammalian model studies, such as those performed in rodents. Therefore, the goal of this study was to map UCN3-producing or ppUCN3 mRNA-expressing neurons in addition to UCN3-ir fibers and terminal fields in the Sapajus spp. monkey brain as a basis for beginning to understand the role of UCN3 in the CNS of primates.

\section{MATERIALS AND METHODS}

\section{Animals and Housing}

Three young male tufted capuchin monkeys (Sapajus spp.), weighing $2-3 \mathrm{~kg}$, were available for use in the present study and were group housed in a vivarium with water and food available ad libitum. The monkeys were provided by the Tufted Capuchin Monkey Procreation of the Araçatuba Dentistry School at 
São Paulo State University (UNESP) in Brazil and this study was carried out in accordance with the recommendations of the Brazilian Institute of Environment and Renewable Natural Resources (IBAMA) regulations and the Institute of Biomedical Sciences Ethical Committee for Animal Research guidelines (approved protocol \#40/2009).

\section{Perfusion and Histological Preparations}

The animals were anesthetized by intraperitoneal injection (ip) of sodium pentobarbital (30 mg/kg) and perfused transcardially $( \pm 1$ liter/10 $\mathrm{min}$ ) with 1 liter of $0.9 \%$ saline. This step was followed by 2 liters of cold $4 \%$ formaldehyde in $0.1 \mathrm{M}$ sodium acetate buffer ( $\mathrm{pH}$ 6.5) and 2 liters of cold $4 \%$ formaldehyde in $0.1 \mathrm{M}$ sodium tetraborate fixative ( $\mathrm{pH} 9.5$ ). Next, the brain, spinal cord and hypophysis were dissected and cryoprotected in two solutions: (1) $10 \%$ glycerol and $2 \%$ DMSO with $0.1 \mathrm{M}$ sodium tetraborate buffer ( $\mathrm{pH}$ 9.5) for 3 days at $4^{\circ} \mathrm{C}$; and (2) $20 \%$ glycerol and 2\% DMSO in $0.1 \mathrm{M}$ sodium tetraborate $(\mathrm{pH} 9.5)$ for 4 days at $4^{\circ} \mathrm{C}$. We followed a formerly described protocol by Bittencourt et al. (1999), what requires no post-fixation time, which promoted superior staining in the immunohistochemical procedures. Next, frontal plane sections of neural axis were obtained in a freezing microtome (SM2000R, Leica, Wetzlar, HE, Germany) with $40 \mu \mathrm{m}$ thickness in eight series and were stored in antifreeze solution at $-30^{\circ} \mathrm{C}$.

The hypophysis was processed for paraffin embedding and $5 \mu \mathrm{m}$ thick histological sections were obtained in a rotary microtome (RM2155, Leica Microsystems, Wetzlar, HE, Germany) and collected the slices on positively charged glass slides (Knittel adhesive slides, Braunschweig, LS, Germany). The histological sections were dried at room temperature, kept at $37^{\circ} \mathrm{C}$ for 2 days in a laboratory incubator and then at $57^{\circ} \mathrm{C}$ for $1 \mathrm{~h}$. The sections were deparaffinized in xylene and then dehydrated in descending grades of alcohol to distilled water. For cytoarchitectonic purposes, one series of slices from each animal undergone Nissl staining (0.025\% thionin). We followed the parcellation described in "A Stereotaxic Atlas of the Brain of the Cebus Monkey" by Manocha et al. (1968), with additional data from "The Rhesus Monkey Brain-In stereotaxic coordinates" by Paxinos et al. (2009). Comparisons to New World monkeys were based on "The marmoset brain in stereotaxic coordinates" by Paxinos et al. (2012).

\section{UCN3 Cloning and Sequencing}

\section{Genomic DNA Extraction}

The DNA extraction procedure was modified from Blin and Stafford (1976). Genomic DNA was utilized for the cloning of UCN3 because there are no intronic sequences in the prepro-hormone encoding gene. One gramme of frozen monkey liver was pulverized into a powder using a mortar and pestle pre-chilled with liquid nitrogen. The powdered tissue was incubated with extraction medium (10 mM Tris- $\mathrm{HCl}(\mathrm{pH} 8.0)$, $0.1 \mathrm{M}$ EDTA, $0.5 \% \mathrm{w} / \mathrm{v}$ sodium dodecyl sulfate, and $20 \mu \mathrm{g} / \mathrm{ml}$ DNAse-free pancreatic RNAse) at $37^{\circ} \mathrm{C}$ for $1 \mathrm{~h}$ in a shaking incubator. Proteinase K $(100 \mu \mathrm{g} / \mathrm{ml})$ was added to the lysate and incubated in a $50^{\circ} \mathrm{C}$ water bath for $150 \mathrm{~min}$. The undigested material was isolated by centrifugation and $1 \mathrm{ml}$ of the supernatant undergone phenol extraction which consisted in mixing samples with an equal volume of phenol and Tris- $\mathrm{HCl}$ solution $\mathrm{pH} 8.0$ several times by inversion. The samples were then centrifuged twice at $5000 \mathrm{rpm}$ for $10 \mathrm{~min}$. The phenol fractions were discarded, the aqueous fraction was mixed with the same volume of chloroform-isoamyl alcohol twice, and then the chloroform fractions were discarded. Next, 2.5 volumes of cold $100 \%$ ethanol were added to 0.1 volume of $3 \mathrm{M}$ sodium acetate and then mixed with the aqueous phase to obtain a DNA precipitate. The precipitated DNA was submitted to centrifugation $5000 \mathrm{rpm}$ for $5 \mathrm{~min}$, followed by two washes in $1 \mathrm{ml}$ of $70 \%$ ethanol, and then it was dried briefly to allow the evaporation of ethanol. The pellet was mixed with $250 \mu \mathrm{l}$ of water to dissolve the genomic DNA. The spectrophotometry was used to determine the DNA concentration, by using a $260 / 280$ absorbance ratio $\left(A_{260 / 280}\right)$.

\section{Polymerase Chain Reaction (PCR) Procedures}

To determine the correct sequence that amplified the translated region of the monkey UCN3 ( $m U C N 3$ ) gene, two kits of oligonucleotides were used, which were based on the human UCN3 sequence. Due to the elevated level of conserved sequence in the mammalian UCN genes, the primers were designed to hybridize with flanking untranslated regions of the UCN3 gene. For the amplification reactions, the nest and semi-nested PCR methods were performed to reduce the non-specific binding, which consisted in a first amplification of the long DNA sequence by using specific primers and then the amplified DNA was used for a second amplification reaction. The PCR occurred in two reactions with a total volume of $50 \mu \mathrm{l}$ (per reaction) containing $29 \mu \mathrm{l}$ of sterile water (RNAse and DNA free), $5 \mu \mathrm{l}$ of PCR buffer supplied with $\left(\mathrm{NH}_{4}\right)_{2} \mathrm{SO}_{4}$ and $1.0 \mathrm{mM}$ $\mathrm{MgCl}_{2}$ (Fermentas, Mississauga, ON, Canada), $2 \mu \mathrm{l}$ of each $10 \mathrm{mM}$ dNTP $(400 \mu \mathrm{M}$ in the final solution, R0192, Fermentas, Mississauga, ON, Canada), $120 \mathrm{ng}$ of DNA, four units of Taq DNA polymerase (1 U/1 $\mu$ l, EP0404, LC Recombinant; MBI-Fermentas) and $2 \mu \mathrm{l}$ of each primer $(0.2 \mu \mathrm{M}$ in the final solution). Primer sequences were as follows: F1 $\left(5^{\prime}-\right.$ atgctgatgccggtccacttc- $\left.3^{\prime}\right)$ and R1 ( $5^{\prime}$-tcctccaatttgcgcatc- $\left.3^{\prime}\right)$. The thermal cycling program consisted of in an initial denaturation phase for $3 \mathrm{~min}$ at $94^{\circ} \mathrm{C}$, and for an amplification sequence of 351 -min cycles at $94^{\circ} \mathrm{C}, 60^{\circ} \mathrm{C}$, and $72^{\circ} \mathrm{C}$. The program concluded with an extension phase at $72^{\circ} \mathrm{C}$ for $5 \mathrm{~min}$. For the second PCR, $3 \mu \mathrm{l}$ of F1/R1 were used as the template, the pairs $\mathrm{R} 1$ and $\mathrm{F} 2\left(5^{\prime}\right.$-cgcaccaagttcaccctgtccctcga- $\left.3^{\prime}\right)$ or R2 $\left(5^{\prime}\right.$ - cctgctgagcaagaggagcttccac- $\left.3^{\prime}\right)$ and F1 were carried out using the same method described previously. The PCR procedures were performed in an Eppendorf Mastercycler thermal cycler (Eppendorf Scientific Inc., Hamburg, Germany).

All the PCR-generated amplification products were separately ligated into the $\mathrm{pCR}^{\circledR} 2.1$-TOPO ${ }^{\circledR}$ plasmid vector (K455040, TOPO TA cloning kit, Invitrogen, Carlsbad, CA, USA) and subcloned using TOP10 cells. Plasmid DNA sequences containing the cloned inserts were isolated using an Eppendorf Perfectprep plasmid miniprep kit (Eppendorf Scientific Inc., Hauppauge, NY, USA). The cloned fragment sizes were confirmed by restriction digestion with EcoR1. All cloned 
fragments were sequenced commercially (ATCG Corp., Toronto, ON, Canada). The subcloned sequences were analyzed by searching for nucleotide and protein sequence similarity using FASTA and NCBI BLAST + software (EMBL-EBI).

\section{In Situ Hybridization}

To investigate and localize the $m U C N 3$ mRNA, we employed

${ }^{35}$ S-labeled antisense cRNA probes in the in situ hybridization protocol, which was adapted from Simmons et al. (1989). Full or partial series of brain sections from three monkeys were perfused and cut as previously described. The tissue was briefly mounted onto adhesion superfrost plus slides (Brain Research Lab, Newton, MA, USA) and fixed in $4 \%$ formaldehyde in $0.1 \mathrm{M}$ phosphate buffered saline (PBS) for $5 \mathrm{~min}$. Protein digestion was performed with $0.001 \%$ proteinase $\mathrm{K}(10 \mathrm{mg} / \mathrm{ml})$ for $15 \mathrm{~min}$ at $37^{\circ} \mathrm{C}$. The samples were then subject to the acetylation by $0.25 \%$ acetic anhydride in $0.1 \mathrm{M}$ triethanolamine (TEA) $\mathrm{pH} 8.0$ for $10 \mathrm{~min}$, followed by rinses in $2 \times$ saline-sodium citrate (SSC). Finally, the tissue was dehydrated in ascending concentrations of ethanol and air dried.

Antisense $m U C N 3$ probes were produced from a 323-bp mUCN3 cDNA which included the entire coding sequence (GenBank $\mathrm{n}^{\circ}$ BC100870.1). The plasmid was designed by subcloning a PCR fragment encoding the part of the coding region of $m U C N 3$ into the EcoRI sites of pCR2.1-TOPO (K455040, TOPO TA cloning kit, Invitrogen, Carlsbad, CA, USA). Labeled antisense $m U C N 3$ probes were produced by linearizing the plasmid with XbaI enzyme. Next, the appropriate RNA polymerase (T7 for anti-sense) was used to synthesize the $m U C N 3$ probe $(323 \mathrm{pb})$. Please, see Supplementary Figure S1 for probe details. The UCN3 probe fragment length was adjusted to 200 nucleotides to reduce alkaline hydrolysis, following the protocol established by Cox et al. (1984) and which was previously described for monkey tissue (Vasconcelos et al., 2003).

The probes were used at concentrations of approximately $10^{6} \mathrm{cpm} / \mathrm{ml}$ in a solution containing $50 \%$ formamide, $0.01 \%$ SDS, $0.3 \mathrm{M} \mathrm{NaCl}, 0.2 \% 5 \mathrm{M}$ dithiothreitol, $10 \mathrm{mM}$ Tris ( $\mathrm{pH} 8.0$ ), $0.01 \%$ tRNA, 1 mM EDTA pH 8.0, $1 \times$ Denhardt's solution, and $10 \%$ dextran sulfate. Next, this hybridization solution $(200 \mu \mathrm{l}$ per section) was applied to monkey tissues and incubated at $56-58^{\circ} \mathrm{C}$, overnight. Monkey sections were treated with $0.002 \%$ RNase A $(20 \mu \mathrm{g} / \mathrm{ml})$ in a solution containing $0.5 \mathrm{M} \mathrm{NaCl}$ and $1 \mathrm{mM}$ EDTA (pH 8.0) at $37^{\circ} \mathrm{C}$ water bath for $30 \mathrm{~min}$. After, the sections were submitted to gradually de-salt (stringency washes) with $1 \mathrm{mM}$ DTT: $2 \times$ SSC at $50^{\circ} \mathrm{C}$ water bath for $1 \mathrm{~h}, 0.2 \times$ SSC at $55^{\circ} \mathrm{C}$ water bath for $1 \mathrm{~h}$ and, $0.2 \times$ SSC at $60^{\circ} \mathrm{C}$ water bath. Sections were dehydrated in a solution of $70 \%$ ethanol with $0.02 \% 2 \times$ SSC and $0.02 \% 5 \mathrm{M}$ DTT for $10 \mathrm{~min}$, air dried at room temperature. The sections were dipped in Kodak NTB-2 liquid autoradiographic emulsion, dried at $37^{\circ} \mathrm{C}$ for $3 \mathrm{~h}$ and then exposed for an average of 4 weeks at $4^{\circ} \mathrm{C}$. The slides were developed with Kodak D-19 and counterstained with $0.25 \%$ thionin for reference purposes.

\section{Antisera Characterization}

All antisera used in this study have been characterized in other studies, and they specifically label the expected group of cells 
(Li et al., 2002; Chen et al., 2011). Labeling specificity was also confirmed by omitting the primary antibodies and by using negative and positive controls in serum with $5 \mathrm{mg} / \mathrm{ml}$ heparin and $2 \%$ bovine serum albumin (blocking solution). To ensure optimal staining with the antisera, we titrated the antibodies as described by Hoffman et al. (2008; see Supplementary Figure S2 for titration details). Please refer to Table $\mathbf{1}$ for additional information regarding the antisera used in the present study.

To ensure the specificity of the antibodies, we used two sets of controls. In the first set, the same immunohistochemistry procedure used to identify UCN3-ir in monkey brain was employed in tissue from both WT mice (wild-type UCN3, $w t / U C N 3$ ) and mice that had the UCN3 gene deleted ("knockout" UCN3, ko/UCN3). These mice were kindly provided by Dr Kuo-Fen Lee from the Peptide Biology Laboratory at The Salk Institute for Biological Studies in La Jolla, CA, USA. The second control employed was a competitive adsorption test, where the antisera were preincubated (overnight at $4^{\circ} \mathrm{C}$ ) with 0-250 $\mathrm{M}$ M synthetic UCN3 (hUCN3, \#415-174-15) or related peptides belonging to the CRF family, such as CRF itself ( $\mathrm{r} / \mathrm{hCRF}$, \#365-198-15) and UCN1 (rUCN, \#351-156-15) and the staining patterns and intensities were analyzed. Peptides were generously provided by Dr Jean Rivier of the Laboratories for Peptide Biology at the Salk Institute. Please, see Supplementary Figures S3-S5 for more details.

\section{Immunohistochemistry}

The "free-floating" sections were briefly pre-treated with a solution of $0.3 \%$ hydrogen peroxide $\left(\mathrm{H}_{2} \mathrm{O}_{2}\right)$ diluted in $0.02 \mathrm{M}$ potassium phosphate buffer (KPBS, $\mathrm{pH}$ 7.4). The tissue was rinsed in KPBS and then was incubated for $48 \mathrm{~h}$ at $4^{\circ} \mathrm{C}$ in the primary anti-hUCN3 antiserum at 1:7000 (see Table 1 for antisera details) with blocking solution (described below). After incubation in primary antibody, the monkey brain sections were washed in KPBS and incubated in a biotin-conjugated secondary antibody solution for $1 \mathrm{~h}$ (1:200; Jackson Immunoresearch Laboratories, West Grove, PA, USA), rinsed in KPBS and then incubated with an avidin-biotin complex solution for $1 \mathrm{~h}(1: 100$, Vectastain Elite; Vector, Burlingame, CA, USA). After KPBS rinses, the tissues were submitted to the peroxidase reaction using $\mathrm{H}_{2} \mathrm{O}_{2}, 3,3^{\prime}$-diaminobenzidine (DAB, Sigma-Aldrich, St. Louis,
MO, USA) as chromogen and nickel ammonium sulfate (NAS, Fisher Scientific, Pittsburgh, PA, USA) as a reaction amplifier. Standard procedures were followed. However, some previously described modifications that had been shown to improve UCN3-ir cell and fiber labeling (Bittencourt et al., 1999) were performed: (1) not pre-treating tissue with sodium borohydride; and (2) incubating tissue in a blocking solution containing $5 \mathrm{mg} / \mathrm{ml}$ of heparin, $2 \%$ bovine serum albumin, $3 \%$ Triton X-100 in KPBS solution for all incubations.

Besides, we used the indirect immunofluorescence technique to study the localization of UCN3 and CRF in the paraventricular nucleus of the hypothalamus (Pa). For UCN3 localization, sections from three different animals were rinsed in KPBS and were incubated for $1 \mathrm{~h}$ in KPBS solution containing $0.03 \%$ Triton X-100, 1\% bovine serum albumin, $5 \mathrm{mg} / \mathrm{ml}$ heparin (blocking solution), followed by incubation over $48 \mathrm{~h}$ at $4^{\circ} \mathrm{C}$ in anti-hUCN 3 antiserum (1:2000, see Table 1 for details of the antisera) diluted in the blocking solution. After rinses in KPBS, sections were incubated in Alexa Fluor ${ }^{\circledR} 594$ donkey anti-rabbit secondary antibody (1:200, Thermo Fisher Scientific, Waltham, MA, USA) diluted in the same blocking solution, for $2 \mathrm{~h}$ at room temperature. After KPBS washes, sections were mounted onto gelatin-coated slides and coverslipped with buffered glycerol medium. For CRF localization, adjacent sections from the same three different animals previously described were rinsed in KPBS, were incubated in blocking solution for $1 \mathrm{~h}$, and then were incubated in anti-r/hCRF (rat/human CRF) antiserum (1:3000, in the same blocking solution; see Table $\mathbf{1}$ for antisera details) over $48 \mathrm{~h}$ at $4^{\circ} \mathrm{C}$. Next, the sections were incubated in Alexa Fluor ${ }^{\circledR} 488$ donkey anti-rabbit secondary antibody (1:200, Thermo Fisher Scientific, Waltham, MA, USA) diluted in the same blocking solution, for $2 \mathrm{~h}$ at room temperature. After KPBS washes, sections were mounted onto gelatin-coated slides and coverslipped with buffered glycerol medium.

We also employed the indirect immunofluorescence technique to study the localization of UCN3 in the hypophysis. Briefly, the sections were washed in $0.1 \mathrm{M} \mathrm{PBS}, \mathrm{pH} 7.4$ and subjected to antigen retrieval using sodium citrate buffer (10 mM sodium citrate, $0.05 \%$ Tween 20, pH 6.0, Sigma-Aldrich, St. Louis, MO, USA) under heat and humid pressure (Decloaking chamber, Model DC2002, Biocare Medical, Pacheco, CA, USA) at $95^{\circ} \mathrm{C}$ for $5 \mathrm{~min}$. The sections were cooled to room temperature
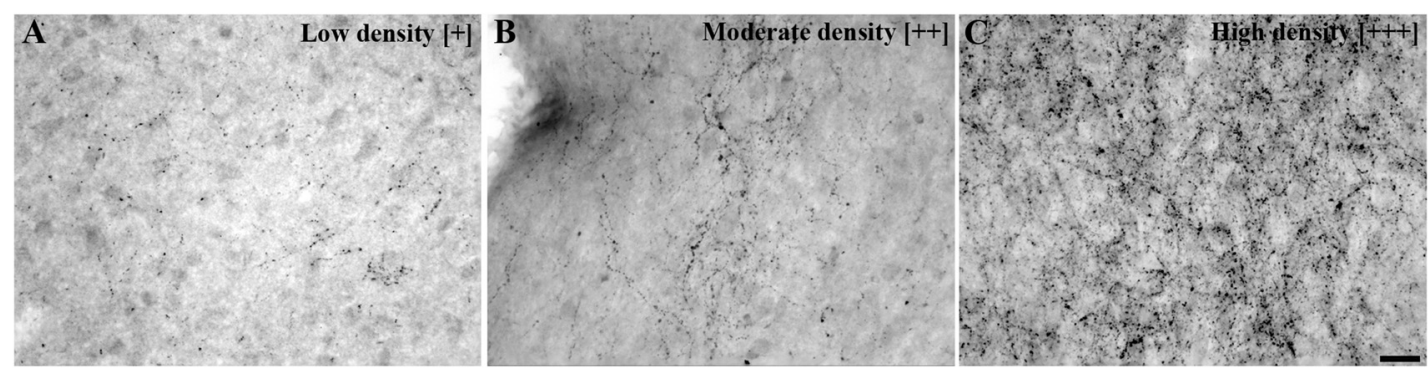

FIGURE 1 | Urocortin 3 immunoreactivity (UCN3-ir) fiber density scale. Bright field photomicrographs showing various UCN3-ir fiber and terminal projection densities: (A) low density [+], (B) moderate density [++], (C) high density [+++] and [-] indicating a complete absence of specific labeling. This scale was used as a reference to perform the fiber density evaluation presented in Table 3. Scale bar: $25 \mu \mathrm{m}$ (A-C) 
and subjected to non-specific blocking using 5\% non-fat milk, followed by secondary blocking using 3\% BSA in PBS/0.3\% Triton X-100 and incubated with anti-hUCN3 antiserum (1:7000, see Table 1 for antisera details) at $4^{\circ} \mathrm{C}$ for $48 \mathrm{~h}$. The sections were first incubated with the specific secondary antibody, followed by streptavidin conjugated with Cy3 (1:500, Jackson Immunoresearch, West Grove, PA, USA), and then they were counterstained with DAPI nuclear stain (Biosensis, Thebarton, SA, Australia). Finally, the histological sections were preserved with buffered glycerol mounting medium and coverslips.

\section{Imaging and Data Analysis}

The images were acquired with a Digital Sight DS-Ril digital camera (Nikon Corporation, Tokyo, Japan) coupled to a Leica microscope (Leica, Wetzlar, HE, Germany) using the image capture software NIS-Elements BR 3.14 (Nikon Corporation, Tokyo, Japan). For the analysis of UCN3 immunofluorescence, the slides were examined under a Leica EL6000 microscope equipped with epifluorescence. The digital photomontages were obtained with a Nikon ECLIPSE 80i microscope connected to a Dell computer that was fitted with the Neurolucida Suite (MicroBrightField, Inc.-MBF, Williston, VT, USA).

Single UCN3-ir and CRF-ir cells in the Pa were analyzed using a confocal laser scanning microscope Zeiss LSM 780 NLO (CarlZeiss AG, Jena, TH, Germany) located at the Centro de Facilidades de Apoio à Pesquisa (CEFAP/USP) at the University of São Paulo.

The presence of cells containing UCN3 mRNA and UCN3-ir cell bodies and fibers were individually evaluated through semiquantitative analysis among the positively labeled regions according to a previously defined rating scale (Figure 1). All images were cropped and adjusted for color balance, brightness, sharpness, and contrast using Adobe Photoshop CS 5.1 version 12.1, 2011.

\section{RESULTS}

\section{Gene Sequencing of Sapajus spp. UCN3}

The mUCN3 gene is 483 bases in length (Figure 2) and has $88 \%$ sequence identity relative to its human cDNA sequence correspondent to the matched region. At the aa level, the Sapajus sequence has 120 aa, of which 21 residues (17.5\%) are substitutions relative to human ppUCN3 and 61 residues are substitutions (50.83\%) relative to rat ppUCN3 (Figure 2). As in humans, the monkey ppUCN3 aa sequence has a three-residue deletion compared to the rat sequence at positions 78-80. The supposed mature sequence of mUCN3 is also 40 aa in size (Figure 2), and only two and four substitutions are related to the human and rat sequences, respectively. No one of the modifications in the mature UCN3 monkey sequence is feasible to preclude functional differences in the peptide.

\section{Antisera Specificity}

Both antisera (PBL\#6570 and PBL\#7218) proved to be specific, based on the results of the controls studies performed. Table 2

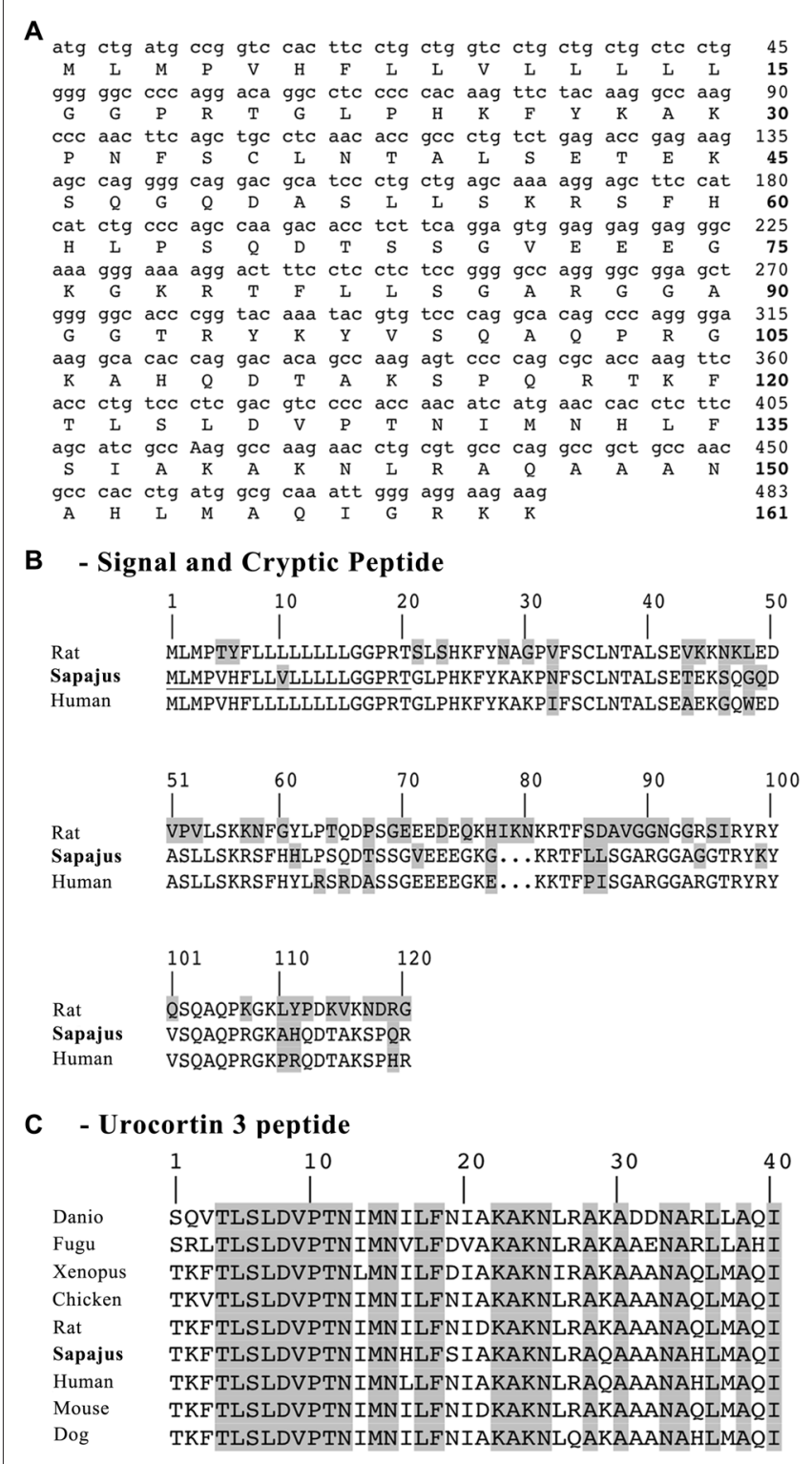

FIGURE 2 | Sapajus prepro-UCN3 (ppUCN3) structure. (A) Nucleotide and amino acid (aa) sequences of the Sapajus prepro-hormone. Corresponding aa are shown below each codon. The numbers on the right indicate base position (normal text) or residue position (boldface). (B) Comparison of the primary structures of rat, monkey and human prepro-UCN3. Boxed residues indicate mismatches relative to the other two sequences. Sequences have been aligned for best fit. (C) Comparison of UCN3 residue sequences of Danio, Danio rerio; Fugu, Tetraodon nigroviridis; Xenopus, Xenopus laevis and tropicalis; Chicken, Gallus; Rat, Rattus norvegicus; Sapajus, Sapajus spp.; Human, Homo sapiens, Mouse, Mus musculus and Dog, Canis lupus. Boxed regions indicate residues that are shared among species.

contains the results of the competition studies. All UCN3-ir staining in the $\mathrm{Pa}$ and in the ventromedial nucleus of the hypothalamus (VMH), which were detected in the control group, were abolished by pre-incubation of the UCN3 antibody for the total UCN3 peptide concentrations employed. Pre-adsorption with CRF or UCN1 diminished but did not eliminate, staining of UCN3-ir cells in the $\mathrm{Pa}$ or fibers in the $\mathrm{VMH}$ when 
TABLE 2 | Competition studies of Urocortin 3 immunoreactivity (UCN3-ir) in the Sapajus spp. monkey brain.

\begin{tabular}{lcc}
\hline Competing peptide & \multicolumn{2}{c}{ Staining } \\
\cline { 2 - 3 } [concentration in mg/ml] & Pa (UCN3-ir cells) & VMHDM (UCN3-ir fibers) \\
\hline UCN3 & & ++ \\
Control & - & - \\
$1 \mathrm{mg} / \mathrm{ml}$ & - & - \\
$0.5 \mathrm{mg} / \mathrm{ml}$ & - & - \\
$0.1 \mathrm{mg} / \mathrm{ml}$ & - & - \\
$0.05 \mathrm{mg} / \mathrm{ml}$ & - & - \\
$0.01 \mathrm{mg} / \mathrm{ml}$ & & +++ \\
UCN1 & + & +++ \\
Control & + & +++ \\
$1 \mathrm{mg} / \mathrm{ml}$ & + & +++ \\
$0.5 \mathrm{mg} / \mathrm{ml}$ & + & +++ \\
$0.1 \mathrm{mg} / \mathrm{ml}$ & + & +++ \\
$0.05 \mathrm{mg} / \mathrm{ml}$ & + & \\
$0.01 \mathrm{mg} / \mathrm{ml}$ & & +++ \\
CRF & + & +++ \\
Control & + & +++ \\
$1 \mathrm{mg} / \mathrm{ml}$ & + & +++ \\
$0.5 \mathrm{mg} / \mathrm{ml}$ & + & +++ \\
$0.1 \mathrm{mg} / \mathrm{ml}$ & + & +++ \\
$0.05 \mathrm{mg} / \mathrm{ml}$ & + & + \\
$0.01 \mathrm{mg} / \mathrm{ml}$ & - & + \\
\hline
\end{tabular}

Staining intensity was rated using a four-point scale: $[++++]$ denotes when labeling intensity was indistinguishable from that achieved using the control antisera [non-pre-adsorbed] and [-] indicates a complete absence of specific labeling. The number of plus signs for the ventromedial nucleus of the hypothalamus, dorsomedial part (NMHDM) represents the density of UCN3-ir fibers, and for paraventricular nucleus of the hypothalamus (Pa), [+] accounts for presence of UCN3-ir cells and [-] represents their absence.

compared to the positive control group. Furthermore, while in $w t / U C N 3$ mice it was possible to observe UCN3-ir cells and fibers in regions that had previously described UCN3-ir (Li et al., 2002), all reactions in $k o / U C N 3$ mice returned negative results (Figure 3).

\section{Cellular Localization of UCN3 Immunoreactivity and mRNA}

In all monkeys examined, we observed UCN3-ir cells were restricted to a few regions in the CNS, mainly in the hypothalamic and amygdaloid regions (Figure 4; Table 3). In the hypothalamus, UCN3-ir neurons were located primarily in the juxtaparaventricular part of the lateral hypothalamus (JPLH), which was located medial to the fornix (f; Figure 4A). This nucleus, in a rostral position in the forebrain, showed the most intense immunostaining when the JPLH was located medial to the fornix and ventrolateral to the dorsal magnocellular part of the $\mathrm{Pa}(\mathrm{PaMD})$ and the dorsal parvocellular part of the $\mathrm{Pa}$ (PaPD; Figures $\left.\mathbf{4} \mathbf{A}^{\prime}, \mathbf{A}^{\prime \prime}\right)$. Neuronal bodies were also found in the periventricular hypothalamic nucleus $(\mathrm{Pe})$, to which the full extent bordered the 3rd ventricle (3V). Few UCN3-ir cells were detected in the supraoptic nucleus (SO), dorsal to the optic tract (opt), dorsolateral to the supraoptic decussation (sox), ventral to the lateral hypothalamic area $(\mathrm{LH})$ and lateral to the anterior hypothalamic area (AH; Figures $\left.\mathbf{4 B}-\mathbf{B}^{\prime \prime}\right)$. There were no UCN3-ir cells in the preoptic area or the MnPO.

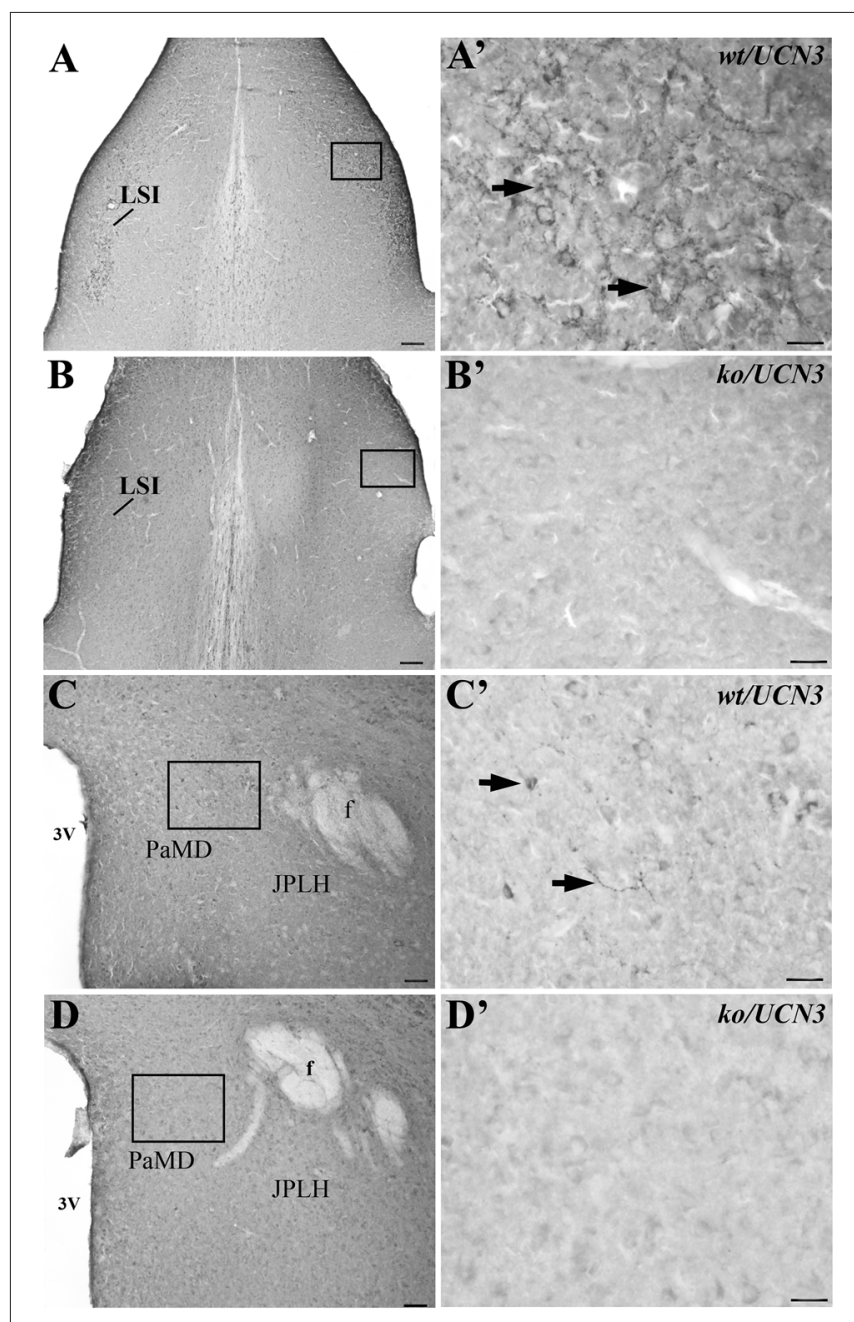

FIGURE 3 | Representative photomicrographs illustrating

UCN3 immunostaining in the intermediate part of the lateral septal nucleus (LSI) and paraventricular hypothalamic nucleus, magnocellular part, dorsal division (PaMD) regions of wild-type UCN3 (wt/UCN3) mice or "knockout" UCN3 (Ko/UCN3) mice. (A) Bright field photomicrograph showing the LSI region of a wt/UCN3 mouse. ( $\mathbf{A}^{\prime}$ ) Higher magnification of (A) UCN3-ir cells and fibers, indicated by black arrows. (B) Bright field photomicrograph showing the LSI region of a ko/UCN3 mouse. ( $\left.\mathbf{B}^{\prime}\right)$ Higher magnification of the square area in (B). Note the absence of labeling. (C) Bright field photomicrograph revealing the PaMD region of a wt/UCN3 mouse. (C') Higher magnification of the square area in (C) showing UCN3-ir cells and fibers, indicated by black arrows. (D) Bright field photomicrograph the PaMD region of a ko/UCN3 mouse. ( $\left.\mathbf{D}^{\prime}\right)$ Higher magnification of the square area in (D). Note the absence of labeling. Scale bars: $100 \mu \mathrm{m}$ (A,B); $50 \mu \mathrm{m}$ (C,D); $20 \mu \mathrm{m}\left(\mathbf{A}^{\prime}-\mathbf{D}^{\prime}\right)$.

In extrahypothalamic areas, UCN3-ir cells were predominantly found in amygdaloid areas, specifically in the medial amygdaloid nucleus (Me; Figures $4 \mathrm{C}-\mathrm{C}^{\prime \prime}$ ). A few UCN3-ir neurons were observed in the cortical nucleus of the amygdala (Co). There were no UCN3-ir cells in regions of the neocortex, brainstem or spinal cord.

We identified the presence of UCN3-ir labeled cells located closely to the area that CRF-ir labeled cells are found in the $\mathrm{Pa}$ (Figure 5). Using confocal microscopy, we observed small UCN3-ir neurons mainly in the dorsal part of PaMD 


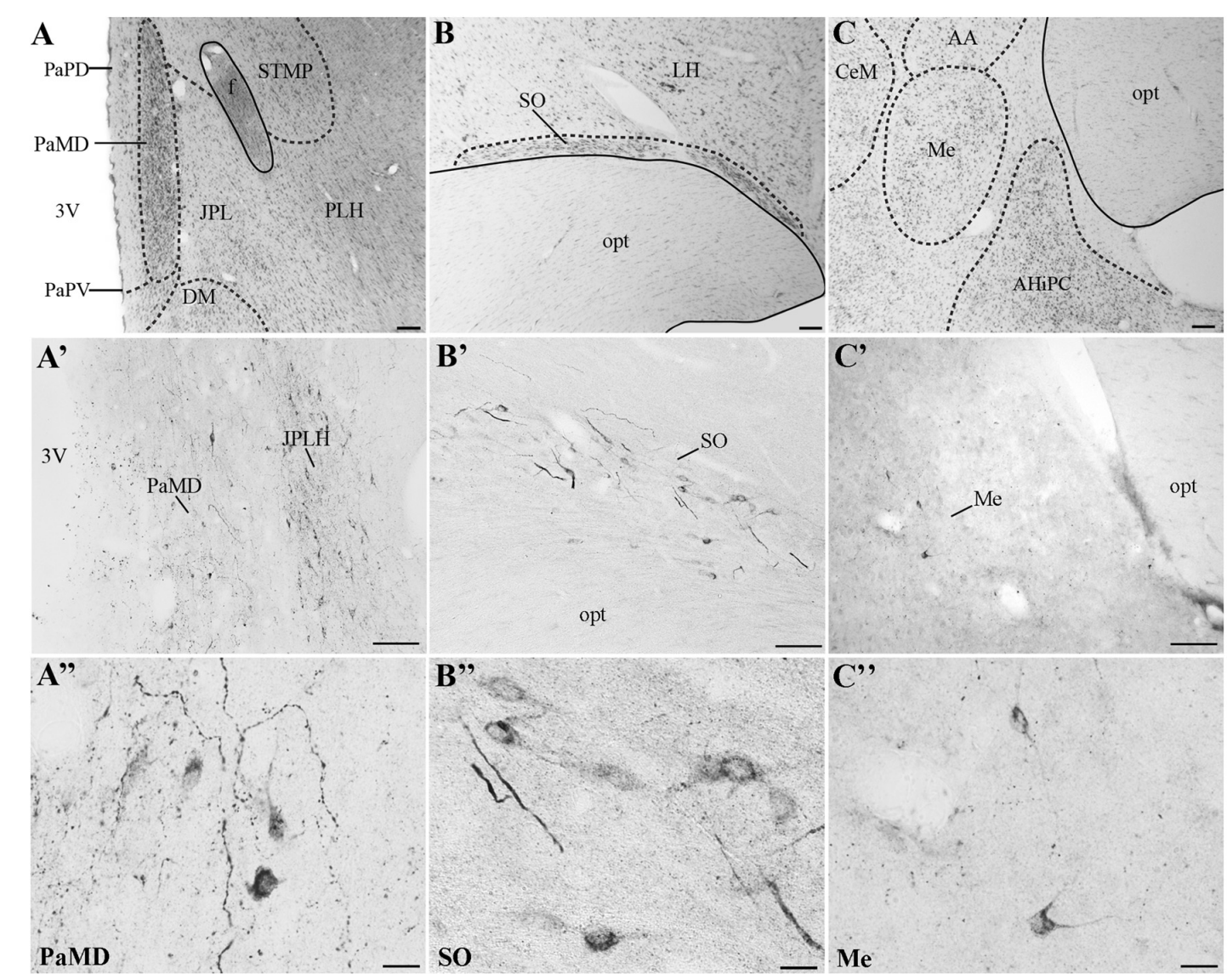

FIGURE 4 | Distribution of UCN3-ir cells in the central nervous system (CNS) of Sapajus spp. A series of bright field images showing representative regions that display the highest densities of UCN3-ir labeled cells. Nissl stained regions of (A) hypothalamus, (B) supraoptic nucleus, (C) amygdala. Dashed lines show nuclear boundaries. ( $\left.\mathbf{A}^{\prime}, \mathbf{A}^{\prime \prime}\right)$ Bright field photomicrographs demonstrating UCN3-ir neurons in the PaMD and juxtaparaventricular part of lateral hypothalamus (JPLH; $\mathbf{B}^{\prime}, \mathbf{B}^{\prime \prime}$ ) in the SO and, $\left(\mathbf{C}^{\prime}, \mathbf{C}^{\prime \prime}\right)$ in the Me. Scale bars: (A,C) $200 \mu \mathrm{m} ;\left(\mathbf{B}, \mathbf{A}^{\prime}, \mathbf{B}^{\prime}, \mathbf{C}^{\prime}\right) 100 \mu \mathrm{m} ;\left(\mathbf{A}^{\prime \prime}-\mathbf{C}^{\prime \prime}\right) 20 \mu \mathrm{m}$.

(Figures 5A, $\mathbf{A}^{\prime}$ ). In contrast, we detected large CRF-ir labeled neurons located primarily in the ventral part of the PaMD (Figures 5B, $\mathbf{B}^{\prime}$ ).

Similar to the immunohistochemical method, the in situ hybridization technique allowed the visualization of UCN3 mRNA expression in restricted regions of the monkey CNS, located predominantly in the hypothalamic and amygdaloid regions (Figure 6). Using light microscopy, we detected neurons with silver grains in the cytoplasm, indicative of UCN3 mRNA expression, in the $\mathrm{MnPO}$ (Figures $\mathbf{6 A}, \mathbf{A}^{\prime}$ ), $\mathrm{PaMD}$ and $\mathrm{PaPD}$ (Figures 6B, $\mathrm{B}^{\prime}$ ) and $\mathrm{SO}$ (Figures $6 \mathrm{C}, \mathrm{C}^{\prime}$ ).

In extrahypothalamic areas, cell bodies with UCN3 mRNA expression were located in the following amygdaloid nuclei: CeM, basomedial amygdaloid nucleus (BM), Me and anterior amygdaloid area (AA) (Figure 6C). UCN3 mRNA expression was also detected in other regions of the monkey CNS, such as the central medial thalamic nucleus (CM), centrolateral thalamic nucleus (CL), paracentral thalamic nucleus (PC), granule cell layer of the dentate gyrus (GrDG) and the anterior (STMA) and ventral (STMV) regions of the medial division of the bed nucleus of stria terminalis (ST). There was no detectable
UCN3 mRNA expression using the UCN3 cRNA sense probe (Figure 7).

\section{UCN 3-ir Projections in the Monkey CNS}

Visualization of fibers and terminal fields occurred predominantly in hypothalamic and limbic regions. The main sites of UCN3-ir fibers were the septal nuclei, such as the intermediate (LSI) and ventral parts (LSV) of the LS. The LSI was the main site of intense UCN3-ir (Figures $\mathbf{8 B}-\mathbf{B}^{\prime \prime}$ ). In the hypothalamus, the dorsomedial part of $\mathrm{VMH}$ (VMHDM) exhibited intense fiber and varicose UCN3-ir unlike the ventrolateral part of the VMH (VMHVL; Figure 8C). The most intense immunostaining for UCN3 was observed at the level where the VMHDM was located ventromedially to the caudal part of the fornix at the level of the lateral tuberal nucleus (LTN; Figures $\left.8 C^{\prime}, C^{\prime \prime}\right)$.

We found moderate to high densities of UCN3-ir fibers in the JPLH, and this was associated with the presence of labeled neurons in this area. A considerable amount of UCN3-ir fibers and varicosities was observed in the following divisions of the $\mathrm{Pa}$ : PaMD, PaPD and the ventral division of the parvicellular 
TABLE 3 | Distribution of UCN3-ir neurons and fibers and UCN3 messenger RNA (mRNA) in Sapajus spp.

\begin{tabular}{|c|c|c|c|}
\hline Cell group & $\begin{array}{l}\text { UCN3-ir } \\
\text { neurons }\end{array}$ & $\begin{array}{l}\text { UCN3-ir } \\
\text { fibers }\end{array}$ & $\begin{array}{l}\text { UCN3 } \\
\text { mRNA }\end{array}$ \\
\hline \multicolumn{4}{|l|}{ Forebrain } \\
\hline \multicolumn{4}{|l|}{ Hippocampal formation } \\
\hline \multicolumn{4}{|l|}{ Dentate gyrus of hippocampal } \\
\hline Field CA1 & - & - & + \\
\hline \multicolumn{4}{|l|}{ Amygdala } \\
\hline Medial nucleus & + & + & - \\
\hline Centromedial nucleus & - & ++ & + \\
\hline \multicolumn{4}{|l|}{ Septal region } \\
\hline Medial septal nucleus & - & + & - \\
\hline Lateral septal, intermediate part & - & +++ & - \\
\hline \multicolumn{4}{|l|}{ Bed nucleus of stria terminalis } \\
\hline Anterior part & - & + & + \\
\hline Ventral part & - & + & + \\
\hline \multicolumn{4}{|l|}{ Diencephalon } \\
\hline \multicolumn{4}{|l|}{ Thalamus } \\
\hline Paraventricular nucleus & - & + & - \\
\hline Medial habenula & - & + & - \\
\hline \multicolumn{4}{|l|}{ Hypothalamus } \\
\hline \multicolumn{4}{|l|}{ Periventricular zone } \\
\hline Median preoptic nucleus & - & - & + \\
\hline Anteromedial preoptic nucleus & - & - & + \\
\hline Supraoptic nucleus & + & + & + \\
\hline \multicolumn{4}{|l|}{ Paraventricular nucleus } \\
\hline Dorsal magnocellular part & +++ & +++ & + \\
\hline Dorsal parvocellular part & + & + & + \\
\hline Ventral parvocellular part & + & + & - \\
\hline Juxtaparaventricular lateral nucleus & +++ & +++ & + \\
\hline Periventricular nucleus & + & ++ & - \\
\hline Median eminence, external zone & - & + & - \\
\hline Arcuate nucleus & + & ++ & - \\
\hline \multicolumn{4}{|l|}{ Medial zone } \\
\hline Lateral preoptic nucleus & - & ++ & + \\
\hline Anterior hypothalamic nucleus & - & - & + \\
\hline $\begin{array}{l}\text { Ventromedial nucleus of } \\
\text { hypothalamus }\end{array}$ & - & +++ & - \\
\hline \multicolumn{4}{|l|}{ Lateral zone } \\
\hline Lateral hypothalamic area & - & + & - \\
\hline \multicolumn{4}{|l|}{ Brainstem } \\
\hline Periaqueductal gray, lateral part & - & + & - \\
\hline $\begin{array}{l}\text { Periaqueductal gray, } \\
\text { ventrolateral part }\end{array}$ & - & + & - \\
\hline \multicolumn{4}{|l|}{ Spinal trigeminal tract nucleus, } \\
\hline caudal part & - & + & - \\
\hline Nucleus of solitary tract & - & + & - \\
\hline \multicolumn{2}{|l|}{ Dorsal motor nucleus of vagus, } & + & - \\
\hline \multicolumn{4}{|l|}{ Hypophysis } \\
\hline anterior lobe & - & - & - \\
\hline posterior lobe & - & ++ & - \\
\hline intermediate lobe & - & - & - \\
\hline
\end{tabular}

The presence of UCN3-ir neurons and fibers, as well as UCN3 mRNA, are indicated by a plus sign, and their absence is indicated by a minus sign. The relative density of UCN3-ir fibers in different brain regions agrees to the patterns shown in Figure 1, indicated by the number of plus signs depending on the amount present in a specific region or with a minus sign to indicate the absence of labeled fibers.

part of the $\mathrm{Pa}$ (PaPV). We also found UCN3-ir fibers and varicosities in the preoptic hypothalamus, specifically in the anteromedial preoptic nucleus (AMPO), medial preoptic area (MPA) and lateral preoptic area (LPO; Figures $\mathbf{8} \mathbf{A}^{\prime}, \mathbf{A}^{\prime \prime}$ ). In the
AMPO, UCN3-ir fibers were mainly located in regions where this nucleus was located ventromedial to the MPA. The MPA was more innervated by UCN3-ir fibers when it was located more dorsolateral to the $3 \mathrm{~V}$, dorsomedial to the AMPO and medial to the LPO. In the LPO, fibers were present when it was located more lateral to the MPA and dorsolateral to the AMPO.

In the median eminence (ME), UCN3-ir fibers were observed in moderate intensity in the external layer (EL), but also in the arcuate hypothalamic nucleus (Arc), where these fibers were transiting to the $\mathrm{ME}$, a pattern that is more evident at rostral levels. Moderately dense UCN3-ir fibers were restricted to the posterior lobe of the hypophysis (PL; Figure 9). Furthermore, it was possible to verify bilateral fibers of the monkey hypothalamo-neurohypophysial tract (hnt; Figure 10).

In extrahypothalamic areas, we found low to moderate UCN3-ir fiber densities in the $\mathrm{Me}$, where it is located lateral to the opt, dorsal to the AA, dorsomedial to the CeM, and ventral to the basomedial amygdaloid nucleus, magnocellular part (BMMC) and the amygdalohippocampal area, parvicellular part (AHiPC). The STMA contains moderately dense UCN3-ir fibers. Few UCN3-ir fibers and varicosities were observed in the medial habenular nucleus $(\mathrm{MHb})$.

In the mesencephalon, some fibers were found in the lateral periaqueductal gray (LPAG) and the ventrolateral periaqueductal gray (VLPAG). In the brainstem, there were few fibers and terminal fields in the solitary nucleus (Sol) and the caudal part of the spinal trigeminal nucleus (Sp5C). Terminal fields were also found in the centrointermediate part of the dorsal motor nucleus of vagus (CeI). There were no UCN3-ir fibers in the entire rostrocaudal axis of the spinal cord.

\section{DISCUSSION}

\section{Methodological Considerations}

Two UCN3 antisera were employed in this study. The first antiserum, PBL\#6570, was used for all experiments, including cell and fiber mapping. The second antiserum, PBL\#7218, was utilized for the image acquisition in some immunohistochemical experiments, but it displayed less specificity when compared to PBL\#6570 and was not used for mapping. Although PBL\#6570 is not species-specific, the adsorption tests demonstrated that it recognized the antigen with high specificity. Additionally, this antiserum labeled the UCN3-ir in the $\mathrm{Pa}$ of brains of other mammals (Li et al., 2002; Chen et al., 2011). Both antisera failed to stain tissue from $k o / U C N 3$ mice, further demonstrating their specificity.

It is worth mentioning that we followed the parcellation for the Cebus monkey (Manocha et al., 1968), compared data to the common New World monkey (Callithrix jacchus, Paxinos et al., 2012) and adopted the nomenclature from the Rhesus monkey (Paxinos et al., 2009) to support our neuroanatomical analysis. This decision was taken because the Sapajus spp. (previously described as Cebus apella) is more comparable in size, sulcal pattern and habits to Old World monkeys of the Macaca genus than to New World monkeys (Gattass et al., 1987; Pinato et al., 2009). Albeit these differences complicate the interpretation of our results obtained using a New World Monkey atlas, we still 


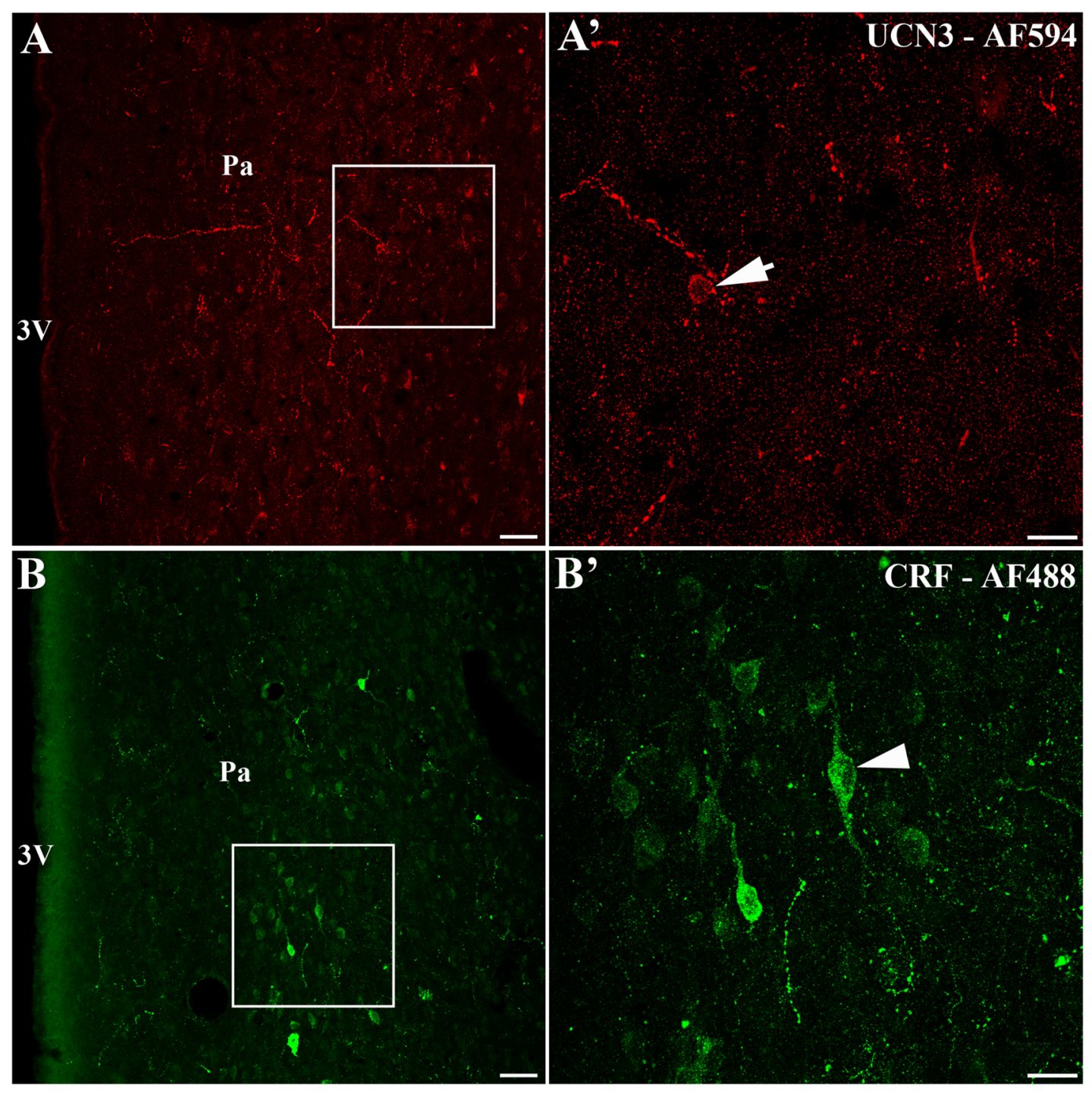

FIGURE 5 | Localization of UCN3-ir and corticotropin-releasing factor (CRF)-ir labeled cells in the paraventricular nucleus of the hypothalamus (Pa) of Sapajus spp. (A) Confocal photomicrograph showing UCN3-ir cells located in the Sapajus Pa. (A') Higher magnification of the square area in (A) demonstrating UCN3-ir labeled cell, indicated by the white arrow. (B) Confocal photomicrograph revealing CRF-ir cells in the region of $\mathrm{Pa}$. (B') Higher magnification of the square area in (B) showing CRF-ir labeled cells, indicated by the white arrowhead. Note the morphological difference between UCN3 (small neuron) and CRF (large neuron) labeled cells in the monkey Pa. Scale bars: (A,B) $50 \mu \mathrm{m} ;\left(\mathbf{A}^{\prime}, \mathbf{B}^{\prime}\right) 20 \mu \mathrm{m}$.

compared the morphological aspects of our data across multiple species (rodents, Rhesus and Marmoset) to highlight conserved aspects of the UCN3 system.

Pre-adsorption with the UCN3 peptide eliminated labeling in both the $\mathrm{Pa}$ and $\mathrm{VMH}$, what did not occur when CRF and UCN1 were used, although pre-adsorption with them diminished labeling. Indeed, among CRF-related peptides, hUCN3 was $32 \%$ similar to hCRF, $21 \%$ similar to hUCN1, $40 \%$ similar to mouse UCN2 and 37\% similar to the human urocortin-related peptide (hURP; Lewis et al., 2001). Therefore, it is likely that those peptides could have some antigenicity to the antisera used in this study. The prepro-hormone sequence of these peptides differs considerably from that of the monkey or human ppUCN3, so it is unlikely that the cRNA probe would hybridize to UCN1, UCN2 or CRF prepro-mRNA. The UCN3 mRNA in the CNS of monkey was mapped using a probe generated from the monkey cDNA sequence. Control studies with the sense probe resulted in no signal.

\section{Morphofunctional Considerations}

\section{UCN3 mRNA Expression and Synthesis}

Here we present the first demonstration of the distribution of UCN3 mRNA and UCN3-ir labeled cells and fibers in the Sapajus spp. monkey brain. The major sites of UCN3 mRNA expression in the monkey CNS are the $\mathrm{Pa}$ and the MnPO, with 

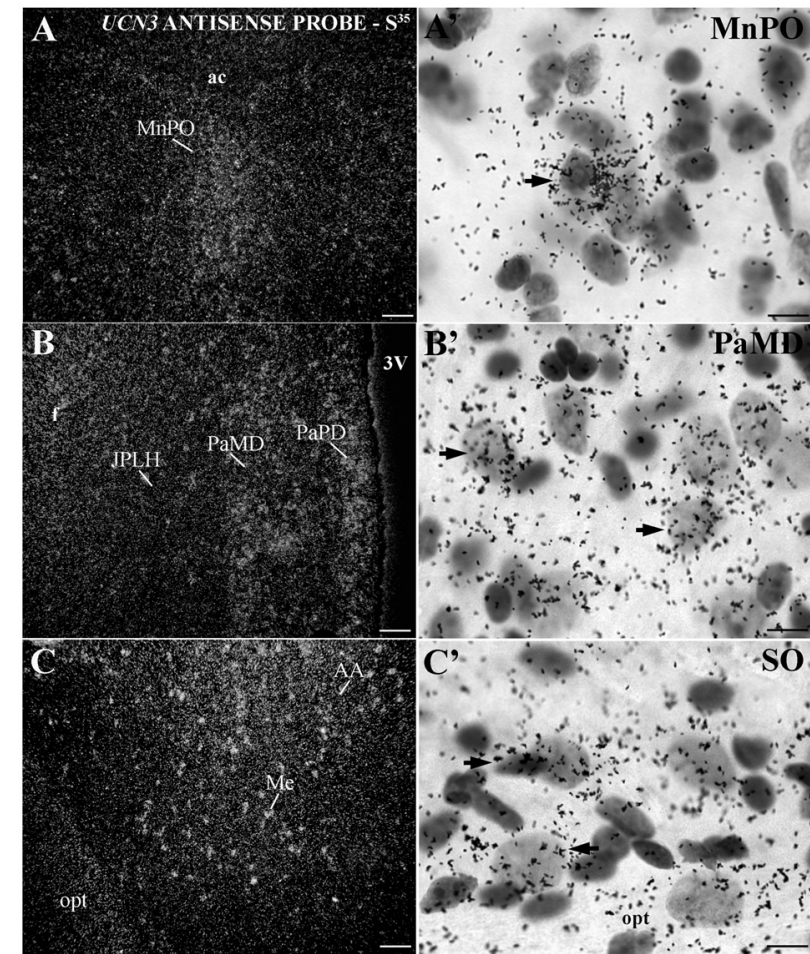

FIGURE 6 | Distribution of UCN3 messenger RNA (mRNA) in the CNS of Sapajus spp. (A-C) A series of darkfield photomicrographs showing UCN3 mRNA expression (silver grains) in the median preoptic nucleus (MnPO), JPLH, PaMD, paraventricular hypothalamic nucleus, parvicellular part, dorsal division (PaPD) and medial amygdaloid nucleus (Me) regions; $\left(\mathbf{A}^{\prime}-\mathbf{C}^{\prime}\right)$ bright field photomicrographs showing silver grains over Nissl-counterstained neurons at higher magnification. Scale bars: (A-C) $50 \mu \mathrm{m} ;\left(\mathbf{A}^{\prime}-\mathbf{C}^{\prime}\right) 10 \mu \mathrm{m}$.

UCN3 mRNA also found in the neurons of the SO and BM; the medial part of the CeM, Me, and AA; and the STMA and STMV. The prevalence of UCN3 mRNA in the hypothalamic and amygdaloid areas contrasts to what occurs with other members of the CRF peptidergic family, especially CRF (Lewis et al., 2001; Li et al., 2002; Venihaki et al., 2004). These results agree with previous studies performed in other species, corroborating the conservation of this neuropeptidergic system (Hsu and Hsueh, 2001; Lewis et al., 2001; Li et al., 2002).

It is noteworthy that UCN3-ir cells could not be found in the monkey $\mathrm{MnPO}$, even though its coding mRNA is present in this region. This result reflects controversial data in the literature regarding UCN3 synthesis in the MnPO, since Lewis et al. (2001) report the $\mathrm{MnPO}$ as the rodent region containing the highest number of mRNA-expressing and immunoreactive cells, while Li et al. (2002) described the presence of only a small group of UCN3-ir cells in this area. When taken together, these data suggest that complex post-translational mechanisms regulate the synthesis of ppUCN3 from its coding mRNA. Furthermore, the $\mathrm{MnPO}$ appears to be especially sensitive to these mechanisms as the presence of UCN3 mRNA does not correlate to neuronal immunoreactivity in this area of the monkey. Zmijewski and Slominski (2010) suggest that alternative splicing and post-translational mechanisms play a major role
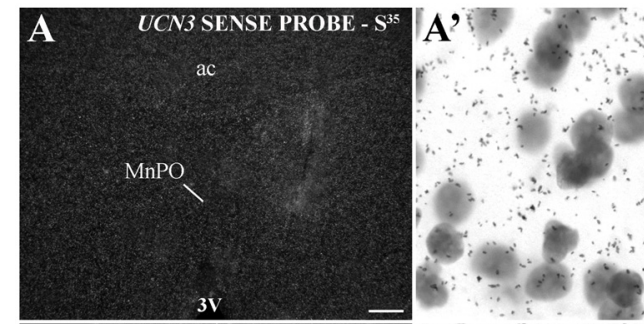

MnPO
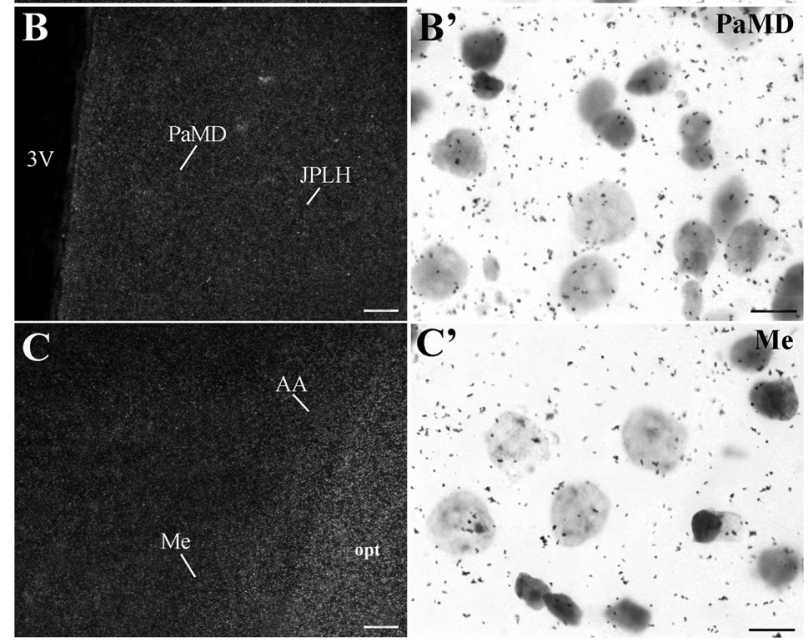

FIGURE 7 | UCN3 mRNA hybridization control in the CNS of Sapajus spp. A series of darkfield and bright field photomicrographs showing that when using a cRNA sense probe for prepro-UCN3, no labeled cells were hybridized. Scale bars: (A-C) $50 \mu \mathrm{m} ;\left(\mathbf{A}^{\prime}-\mathbf{C}^{\prime}\right) 10 \mu \mathrm{m}$.

in CRF communication, and these mechanisms may have been conserved in other members of the CRF family; however, little is currently known about the specific modifications related to UCN3 production.

In the monkey hypothalamus, two regions concentrate UCN3-ir neurons, the JPLH and the Pa. Like the mRNA distribution, UCN3 synthesis is similar to what is observed in other species, once again indicating that the peptidergic system is well conserved (Hsu and Hsueh, 2001; Lewis et al., 2001; Li et al., 2002; Table 4). The first group, the JPLH, is a region located between the fornix and $\mathrm{Pa}$ which corresponds in rodents to the rostral PFA. Kuperman et al. (2010), using targeted overexpression of UCN3 in the PFA, showed that these neurons regulate anxiety-related behaviors, energy expenditure and glucose metabolism by projecting to the LS and the $\mathrm{VMH}$. Therefore, they suggest that $\mathrm{UCN} 3$ and its receptor, $\mathrm{CRF}_{2}$, constitute the main component of brain responses to physiological and psychological changes. A similar synthesis of UCN3 by neurons in the JPLH could indicate that UCN3 has conserved its role in the three behavioral responses to stress in primates.

There is evidence that UCN3 is a highly synergistic peptide. As described by Wittmann et al. (2009), almost all UCN3-ir cells in the PFA produce thyrotropin-releasing hormone (TRH), while approximately half of all BNST neurons are UCN3/TRH. They also report that double-labeled UCN3/TRH neurons densely 

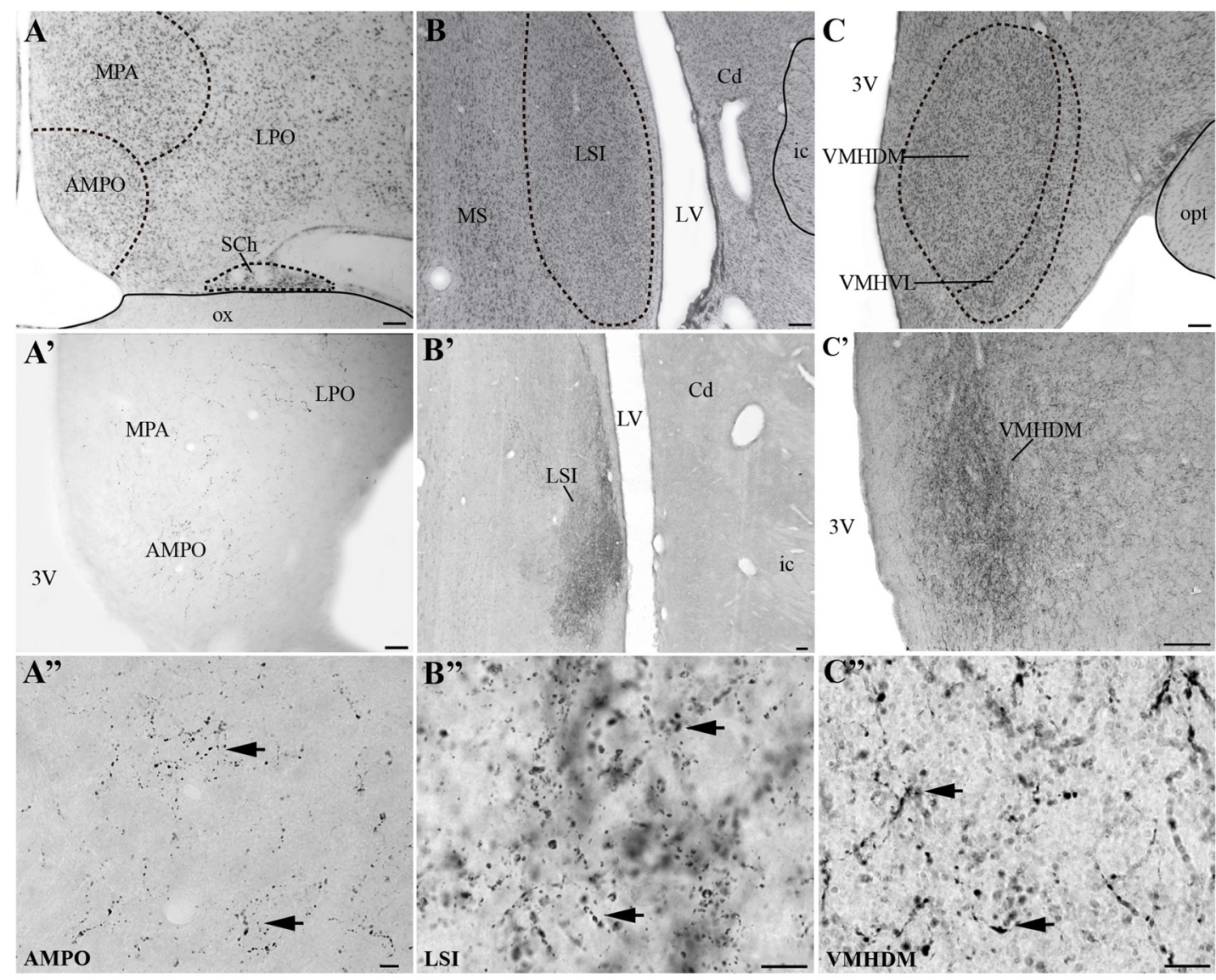

$\mathrm{Cd}$
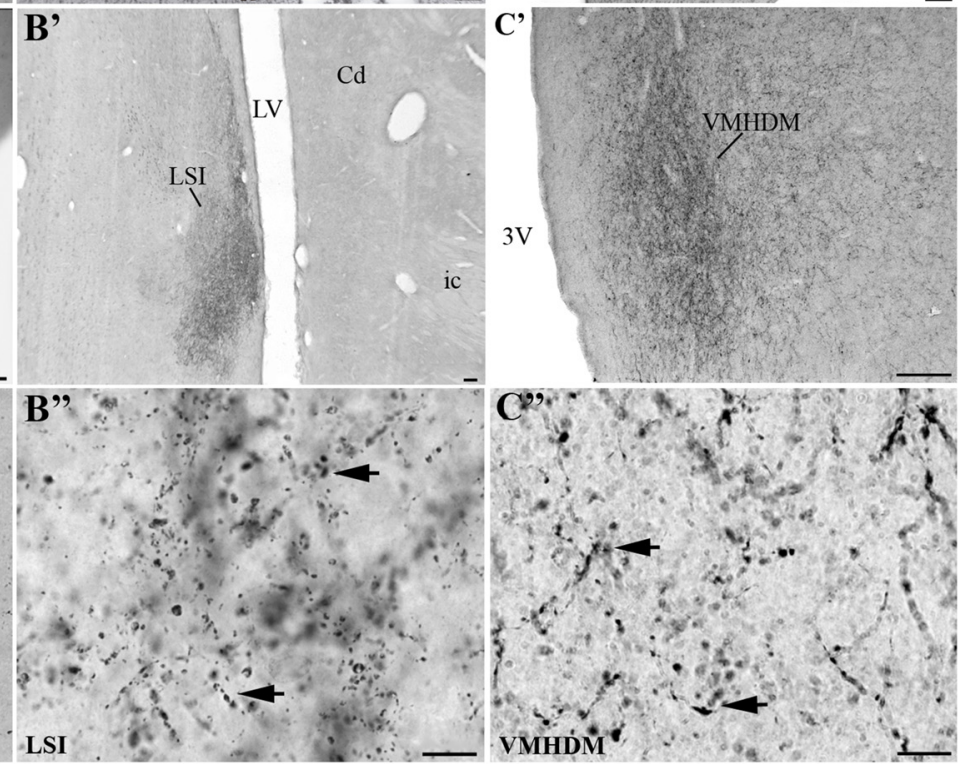

FIGURE 8 | Distribution of UCN3-ir fibers in the CNS of Sapajus spp. A series of bright field photomicrographs of selective innervation by UCN3-ir fibers in discrete regions of the monkey brain. (A-C) Are Nissl-stained sections of representative areas with overlays indicating the structure boundaries. $\left(\mathbf{A}^{\prime}\right)$ Preoptic area; $\left(\mathbf{B}^{\prime}\right)$ LSI

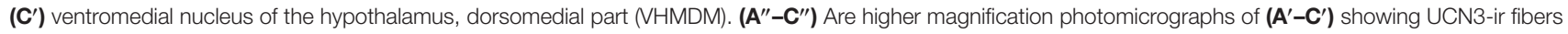
and terminals. Please note UCN3-ir fibers and varicosities (black arrows) and the very dense amount of UCN3-ir fibers in LSI and VMHDM in (B' $\mathbf{B}^{\prime}, \mathbf{C}^{\prime}$ ). Scale bars: (A-C) $200 \mu \mathrm{m} ;\left(\mathbf{A}^{\prime}\right) 50 \mu \mathrm{m} ;\left(\mathbf{B}^{\prime}, \mathbf{C}^{\prime}\right) 100 \mu \mathrm{m} ;\left(\mathbf{A}^{\prime \prime}-\mathbf{C}^{\prime \prime}\right) 10 \mu \mathrm{m}$.

innervate the VMH. In addition, injection of UCN3 into the VMH decreases food intake (Fekete et al., 2007; Li et al., 2007) similar to injections of TRH, reinforcing that PFA UCN3 cells may be involved in food intake and glucose metabolism regulation, most likely in association with the TRH peptidergic system through the VMH in rodents.

Fekete et al. (2007) also reported a similar observation concerning the intracerebroventricular (icv) administration of leptin, suggesting a possible functional relationship between leptin and $\mathrm{CRF}_{2}$ in the $\mathrm{VMH}$ to the modulation of homeostasis (Fekete et al., 2007; Kuperman and Chen, 2008). Since there the presence of UCN3-ir labeled cells in the monkey JPLH associated with UCN3-ir fibers in the ST and VMH, taken together, these data suggest an anatomical substrate for the same regulation in primates, although more studies are necessary to clarify this function in rodents and primates.

The second group, located at caudal levels of the PaMD with moderate UCN3-ir labeled cells, was also identified in the neighboring PaPD, by immunoperoxidase and immunofluorescence. As established by Chen et al. (2011), the main UCN3 innervation of the VMH arises from the PVH and the posterior BNST, while the more posterior PFA neurons contribute more to the innervation of the LS. Interestingly, $\mathrm{UCN} 3$ injections into the PVH also have an anorectic effect, once more indicating the participation of UCN3 in energy homeostasis regulation (Chen et al., 2011). Recently, the same group showed that there are reciprocal connections between $\mathrm{VMH}$ and anterior parvicellular part of the paraventricular nucleus of the hypothalamus (PVHap; van-Hover and $\mathrm{Li}$, 2015). Thus, this could be related to the modulation of the stress-associated behavior. The abundance of UCN3-ir cells in the $\mathrm{Pa}$ of Sapajus suggests a similar anatomical basis for this regulation in monkeys. The former group also described that PVHap receives information from different areas, such as LS, bed nucleus of the stria terminalis (BST) and amygdala, these nuclei are implicated in the modulation of learning and behavior, concerning autonomic regulation. These findings confirmed that the expression of $U C N 3$ in the MeA is sensitive to stress (Jamieson et al., 2006), and that the restraint stress increases the UCN3 expression in the PVHap and BST, but no alteration was 
TABLE 4 | Comparison between the distribution of UCN3-ir fibers and $C_{2} F_{2}$ mRNA in selective regions of monkeys and rat brains.

\begin{tabular}{|c|c|c|}
\hline Region & $\begin{array}{l}\text { Sapajus/Rhesus } \\
\text { UCN3-ir } \\
\text { Fibers/CRF } 2 \\
\text { mRNA }^{a}\end{array}$ & $\begin{array}{l}\text { Rattus } \\
\text { UCN3-ir } \\
\text { Fibers }^{\mathrm{b}} / \mathrm{CRF}_{2} \\
\text { mRNA }^{\mathrm{c}}\end{array}$ \\
\hline \multicolumn{3}{|l|}{ Forebrain } \\
\hline \multicolumn{3}{|l|}{ Amygdala } \\
\hline Central nucleus & $++/+$ & $-1-$ \\
\hline Medial nucleus & $+/-\mid+$ & $+++/++$ \\
\hline \multicolumn{3}{|l|}{ Septum } \\
\hline Lateral nucleus & $+++/++$ & $++++/++++$ \\
\hline \multicolumn{3}{|l|}{ Bed nucleus, stria terminalis } \\
\hline Rostral region & $+/++$ & $+/-$ \\
\hline Posterior region & $+/++$ & $+++/++$ \\
\hline \multicolumn{3}{|l|}{ Hypothalamus } \\
\hline Arcuate nucleus & $++/ \mathrm{NA}$ & $++/+$ \\
\hline Medial preoptic nucleus & ++ NA & $+++/+\mid++$ \\
\hline \multicolumn{3}{|l|}{ Paraventricular nucleus } \\
\hline Parvicellular part & $+/+++$ & $+/+$ \\
\hline Magnocellular part & $+++/+++$ & $+/+$ \\
\hline Supraoptic nucleus & $+/+++$ & $-\mid+/++$ \\
\hline Ventromedial nucleus & $+++/+++$ & $++++/+++$ \\
\hline \multicolumn{3}{|l|}{ Hindbrain } \\
\hline Nucleus of tract solitary & $+/-$ & $-/++$ \\
\hline Periaqueductal gray & $+/ \mathrm{NA}$ & $+\mid++/+$ \\
\hline
\end{tabular}

The presence of UCN3-ir fibers [Sapajus and Rattus ${ }^{b}$ ] a CRF 2 MRNA [Rhesus ${ }^{a}$ and Rattus $^{C}$ are indicated by a plus sign, and their absence is indicated by a minus sign. The relative density of Sapajus UCN3-ir fibers in different brain regions agrees to the patterns shown in Figure 1, indicated by the number of plus signs depending on the amount present in a specific region or with a minus sign to indicate the absence of labeled fibers, and non-available data is indicated by NA. ${ }^{a}$ Adapted from Sánchez et al. (1999). ${ }^{b}$ Adapted from Li et al. (2002). ' Van Pett et al. (2000).

found in the rostral perifornical hypothalamus (van-Hover and Li, 2015). Despite the phylogenetic differences between rodents and monkeys, it is possible that this mechanism is conserved in non-human primates.

Nevertheless, a possible role for $\mathrm{UCN} 3$ in the $\mathrm{Pa}$ is not restricted to the modulation of motivational behaviors. Li et al. (2010) reported the involvement of UCN3 on the cardiovascular activity in rats. Following icv injections of UCN3 into the $\mathrm{PVH}$, they observed a significant increase in systolic blood pressure, heart rate and renal sympathetic activity, implying that UCN3 plays a role in the neural control of cardiovascular function, by increasing sympathetic outflow through $\mathrm{CRF}_{2}$ activation in the PVH. Consistent with this notion, and comparing the functional data from the literature to our anatomical data, we suggest that UCN3 could have the similar functions in monkeys that it has in rodents through the Pa.

\section{UCN3-ir Projections in Monkey CNS}

The distribution of UCN3-ir fibers is restricted to some diencephalic territories displaying a very dense innervation. Among all regions, the most prominent UCN3-ir terminal fields are found in the VMHDM and the LSI; this finding is in full agreement with the UCN3 innervation density observed in the rodent brain (Li et al., 2002).

The VMH, Arc, lateral hypothalamus and PVH nuclei are important regions related to the central regulation of feeding,

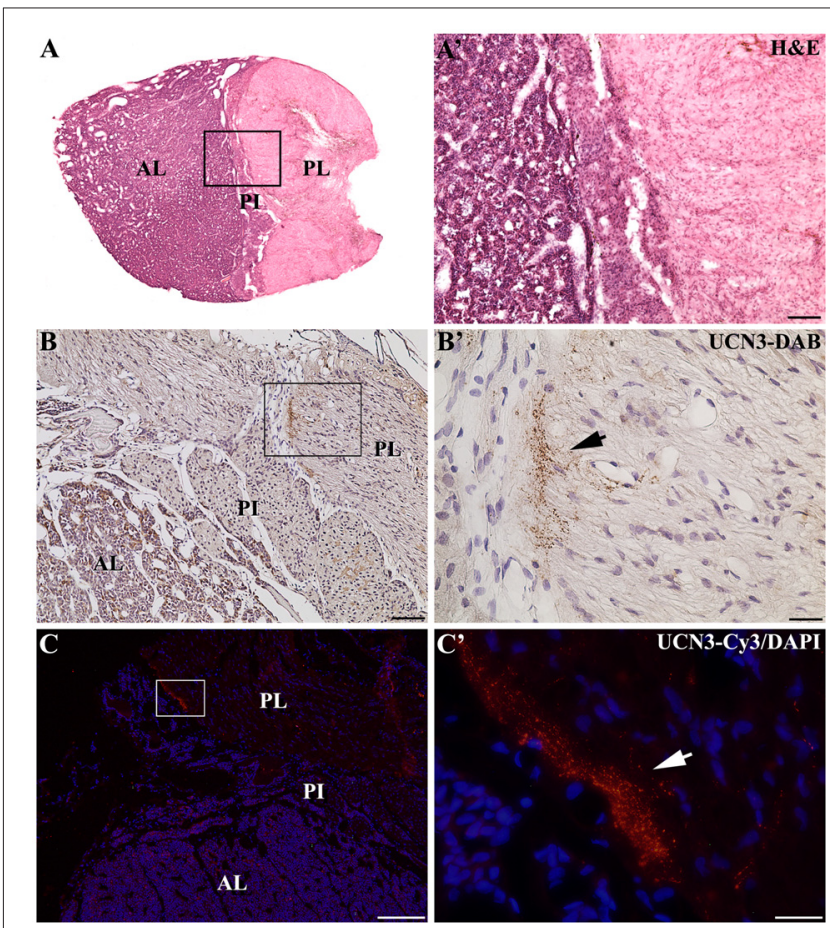

FIGURE 9 | Distribution of UCN3-ir fibers in the hypophysis of Sapajus spp. (A) Photomontage of bright field photomicrographs of the entire Sapajus pituitary histology by H\&E staining showing the clear distinction between the anterior lobe $(\mathrm{AL})$, pars intermedia $(\mathrm{PI})$ and posterior lobe $(\mathrm{PL})$. ( $\left.\mathbf{A}^{\prime}\right)$ Higher magnification of $(\mathbf{A})$ demonstrating the boundaries between the $A L, P I$ and $P L$. (B) Bright field photomicrograph showing UCN3-ir fibers in the posterior lobe. $\left.\mathbf{( B}^{\prime}\right)$ Higher magnification of the square area in $(\mathbf{B})$ showing an UCN3-ir bundle of fibers, indicated by the black arrow; (C) Fluorescence photomicrograph of UCN3-ir fibers in the posterior lobe; $\left(\mathbf{C}^{\prime}\right)$ higher magnification of the square area in $\mathbf{( C )}$ showing an UCN3-ir bundle of fibers, indicated by the white arrow.

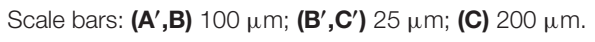

glucose homeostasis and energy balance and, also express high levels of $C_{2} F_{2}$ (Lovenberg et al., 1995b; Van Pett et al., 2000; Li et al., 2002; Chen et al., 2005; Kuperman and Chen, 2008). There is also a partial overlap between the distribution of UCN3-ir fibers in the Sapajus spp. brain and the $\mathrm{CRF}_{2}$ mRNA expression sites in both rodents and non-human primates (Sánchez et al., 1999; Van Pett et al., 2000; Li et al., 2002).

Most $\mathrm{CRF}_{2}$-expressing neurons in the $\mathrm{VMH}$ have a glutamatergic excitatory activity, and a subset of those cells project to the $\mathrm{ARH}$, more specifically to POMC-producing neurons (Chen et al., 2010). The ARH nucleus is recognized as a key anorectic component of the CNS, but it also plays a major role in regulating blood glucose levels (Chen et al., 2010). Thus, because activation of $\mathrm{VMH} \mathrm{CRF}_{2}$ positive neurons leads to the stimulation of POMC cells in the ARH, food and blood glucose homeostasis can be achieved through UCN3 modulation (Chen et al., 2010). This result was further confirmed by Chen et al. (2011) by performing icv injections of UCN3 into the $\mathrm{VMH}$ of rats, which led to increased blood glucose levels, suppressed food intake and increased expression of POMC mRNA in the ARH. However, there was no activation of the hypothalamic-pituitary-adrenal axis (HPA) when compared to 


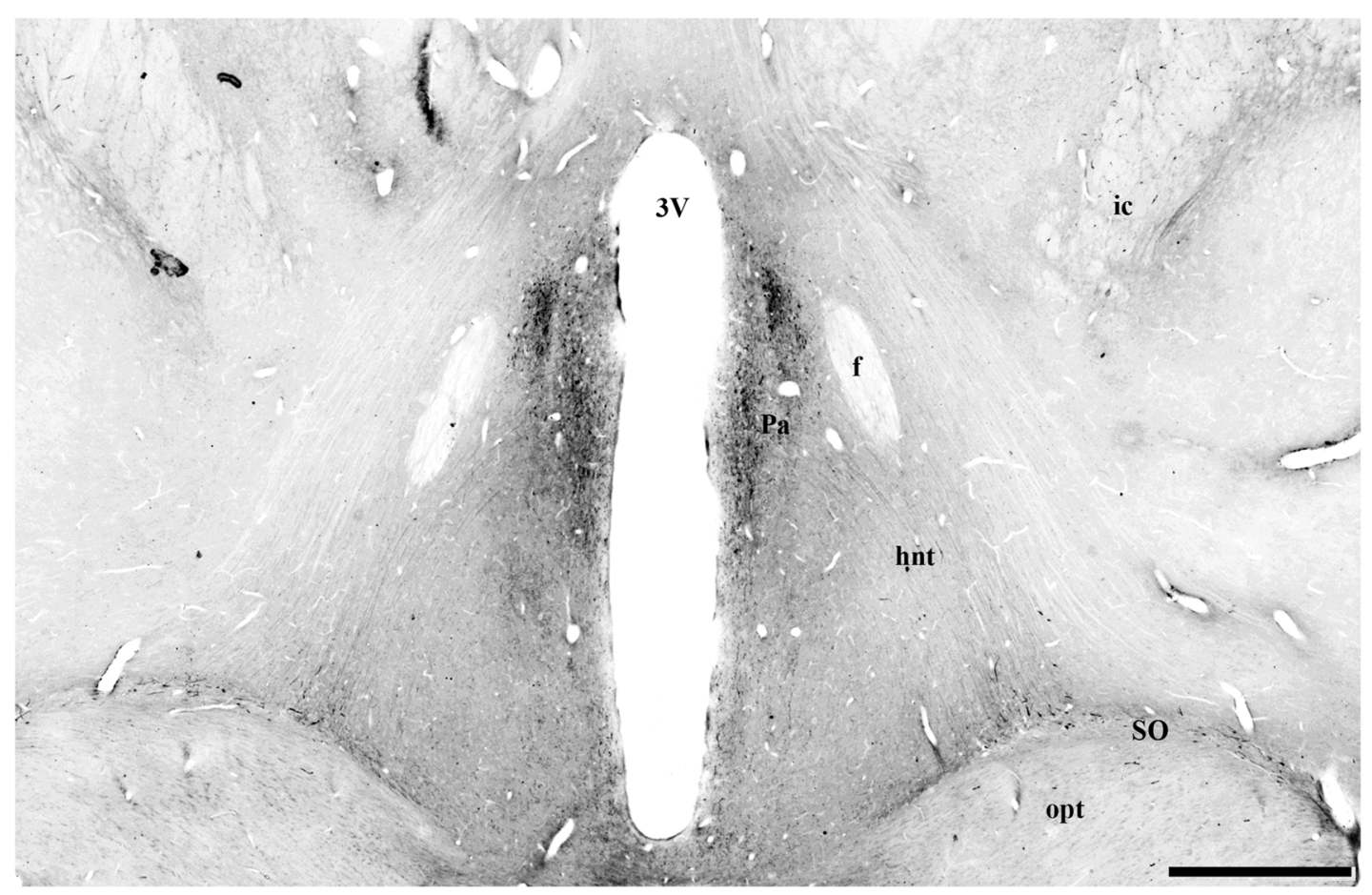

FIGURE 10 | Digital photomontage of the hypothalamo-neurohypophysial tract (hnt) of Sapajus spp. Note the UCN3-ir cells in the paraventricular nucleus of the hypothalamus and their stained UCN3 fibers leaving this group of cells in a descending pathway towards the median eminence (ME) and posterior hypophysis through the hypothalamic-pituitary tract, which is visualized bilaterally. Scale bar: $1000 \mu \mathrm{m}$.

the control group. These findings suggest that $\mathrm{CRF}_{2}$ activation could modulate these nuclei, and that UCN3 neurons in these nuclei could be involved in modulating energy balance and homeostasis.

In rats, Singewald et al. (2011) hypothesized that the LS exerts a modulatory role in behavioral and neuroendocrine responses to stress. These authors report that the rat LSI plays a vital role in promoting an inhibitory influence over the HPA unlike the negative feedback mechanism of glucocorticoids. It also plays a role in enabling response strategies during exposure to stress. Thus, they support the hypothesis that LS neuronal activity is needed to cope with stress responses and provide protection against the deleterious effects of excessive exposure to psychological stress (Singewald et al., 2011).

Regarding the regions of mismatch, Sánchez et al. (1999) described that the choroid plexus region has the highest signal following in situ hybridization for the $\mathrm{CRF}_{2}$ mRNA in Rhesus monkeys. Although some UCN3 fibers are found near ependymal cells around the third ventricle, this innervation density is lower compared to the $\mathrm{CRF}_{2}$ mRNA expression in the choroid plexus. This finding suggests that UCN3 is not the main peptide that binds $\mathrm{CRF}_{2}$ in the choroid plexus. In the hypophysis, a similar mismatch occurs because UCN3-ir fibers are found in the Sapajus posterior lobe, while $C_{2} F_{2}$ mRNA is found exclusively in the anterior lobe (AL) of the Rhesus monkey (Sánchez et al., 1999).
Interestingly, this hypophysial distribution of UCN3-ir fibers in Sapajus spp. agrees with the $C R F_{2}$ mRNA distribution in rats found by Van Pett et al. (2000), which could reflect a possible divergence in the neuroendocrine mechanisms for the $\mathrm{UCN} 3 / \mathrm{CRF}_{2}$ system between New and Old World monkeys (Table 4).

This partial overlap between UCN3-ir fibers and $C R F_{2}$ mRNA expression in primates has been similarly reported in rodents by Li et al. (2002). Conversely, Vasconcelos et al. (2003) also described limited matching regions between UCN1-ir fibers in the monkey CNS and the rodent $\mathrm{CRF}_{2}$ mRNA distribution (Chalmers et al., 1995; Van Pett et al., 2000). Nevertheless, the areas with the densest innervation of UCN3-ir fibers correlate with those containing $\mathrm{CRF}_{2}$ in other animal models (Lewis et al., 2001; Li et al., 2002; Jamieson et al., 2006; Kuperman et al., 2010), which therefore, suggests that UCN3 has been conserved as one of the endogenous ligands for $\mathrm{CRF}_{2}$ in non-human primates.

Since UCN3 is the only member of the CRF family which is a highly selective ligand for $\mathrm{CRF}_{2}$ (Lovenberg et al., 1995a; Hsu and Hsueh, 2001; Lewis et al., 2001; Deussing et al., 2010), we believe that the UCN3-ir fiber distribution provides an anatomical basis for UCN3 modulation of physiological effects related to endocrine and behavioral responses to stress in primates similar to rodents (Reul and Holsboer, 2002; Venihaki et al., 2004; Jamieson et al., 2006; Chen et al., 2010, 2012).

Venihaki et al. (2004) reported that UCN3 participated in the modulation of stress by alleviating some anxiety-related 
behaviors, despite UCN3 not affecting the activity of the HPA axis. The anxiolytic effects of UCN3 may serve two purposes. First, UCN3 may limit the extent of behavioral response to stress and thus may be beneficial for preventing excessive anxiety, which, in turn, may be an appropriate response to a stressful situation. Second, this limitation of the stress response may prevent the emergence of pathological responses to stress, which are one of the leading causes of psychiatric diseases, such as chronic anxiety disorders and depression in humans (Venihaki et al., 2004). The data presented here for Sapajus spp. further strengthen this notion, indicating that the UCN3 peptidergic system is optimally located to mediate and modulate stress responses in non-human primates.

\section{CONCLUSION}

The main sites of UCN3-producing neurons in Sapajus spp. are the paraventricular nucleus of the hypothalamus, the PFA and the juxtaparaventricular lateral nucleus, which are similar to those described for rodents. The presence of UCN3-ir fibers mainly in the ventromedial nucleus of the hypothalamus, paraventricular nucleus of the hypothalamus and in the LSI is coincidental to the $\mathrm{CRF}_{2}$ distribution in the Rhesus monkey. When taken together, these data suggest that UCN3 plays a role in stress responses and neuroendocrinological control.

\section{AUTHOR CONTRIBUTIONS}

In this study, all authors had full access to the data and take responsibility for the data integrity and the accuracy of the data analysis. JCB: study concepts and design; study supervision. DSB: acquisition of the data. DSB and JCB: analysis and interpretation of the data; obtained funding. DSB, JCB, GBD: drafting of the manuscript. JCB, CFPL, DAL, LVS: critical revision of the manuscript for important intellectual content. PLC, JAO, CAC, KRTS, JMS, ARO: administrative, technical and material support.

\section{REFERENCES}

Alfaro, J. W. L., Silva, J. D. S. E., and Rylands, A. B. (2012). How different are robust and gracile capuchin monkeys? An argument for the use of Sapajus and Cebus. Am. J. Primatol. 74, 273-286. doi: 10.1002/ajp.22007

Bittencourt, J. C., Vaughan, J., Arias, C., Rissman, R. A., Vale, W. W., and Sawchenko, P. E. (1999). Urocortin expression in rat brain: evidence against a pervasive relationship of urocortin-containing projections with targets bearing type 2 CRF receptors. J. Comp. Neurol. 415, 285-312. doi: 10.1002/(sici)10969861(19991220)415:3<285::AID-CNE1>3.0.CO;2-0

Blin, N., and Stafford, D. W. (1976). A general method for isolation of high molecular weight DNA from eukaryotes. Nucleic Acids Res. 3, 2303-2308. doi: 10.1093/nar/3.9.2303

Chalmers, D. T., Lovenberg, T. W., and De Souza, E. B. (1995). Localization of novel corticotropin-releasing factor receptor (CRF2) mRNA expression to specific subcortical nuclei in rat brain: comparison with CRF1 receptor mRNA expression. J. Neurosci. 15, 6340-6350.

Chen, P., Hover, C. V., Lindberg, D., and Li, C. (2012). Central urocortin 3 and type 2 corticotropin-releasing factor receptor in the regulation of energy

\section{FUNDING}

This study was supported by Fundação de Amparo à Pesquisa do Estado de São Paulo (São Paulo State Foundation for the Support of Research, FAPESP), grant $n^{\circ} 2004 / 13849-5$ and 2016/02224-1 to JCB, grant $n^{\circ} 2011 / 09816-8$ to LVS, grant $n^{\circ} 2006 / 07016-6$ to CFPL, grant $n^{\circ} 2016 / 02748-0$ to GBD, grant $\mathrm{n}^{\circ} 2012 / 03067-6$ to CAC, and grant $\mathrm{n}^{\circ} 2012 / 08833-9$ to KRTS. DAL was supported by the Natural Sciences and Engineering Research Council (NSERC) of Canada, and DSB was a fellowship recipient (FAPESP grant $n^{\circ}$ 2009/06769-9). We would also like to thank Coordenação de Aperfeiçoamento de Pessoal de Nível Superior (CAPES, Agency for the Advancement of Higher Education). JCB is an investigator with the Conselho Nacional de Desenvolvimento Científico e Tecnológico (CNPq, National Council for Scientific and Technological Development).

\section{ACKNOWLEDGMENTS}

We would like to thank Dr. Jean Rivier and Joan Vaughan (Laboratories of Peptide Biology), Carlos M. Arias and Paul E. Sawchenko (Laboratory of Neuronal Structure and Function), The Salk Institute for Biological Studies in La Jolla, CA, USA, for generously giving us the peptides, antisera, and technical help; JAS for providing the Sapajus spp. monkeys, José Ari Gualberto Junqueira and Arnaldo César dos Santos for the generous technical assistance ("Tufted Capuchin Monkey Procreation Center", School of Dentistry at São Paulo State University in Araçatuba, Brazil), and Dr. Kuo-Fen Lee (Laboratories of Peptide Biology, The Salk Institute for Biological Studies in La Jolla, CA, USA) for generously providing the "knockout" mice (ko/UCN3) and "wild-type" mice ( wt/UCN3) that were used in this research.

\section{SUPPLEMENTARY MATERIAL}

The Supplementary Material for this article can be found online at: http://journal.frontiersin.org/article/10.3389/fnana. 2017.00057/full\#supplementary-material

homeostasis: critical involvement of the ventromedial hypothalamus. Front Endocrinol. 3:180. doi: 10.3389/fendo.2012.00180

Chen, P., Lin, D., Giesler, J., and Li, C. (2011). Identification of urocortin 3 afferent projection to the ventromedial nucleus of the hypothalamus in rat brain. J. Comp. Neurol. 519, 2023-2042. doi: 10.1002/cne.22620

Chen, A. M., Perrin, M. H., Digruccio, M. R., Vaughan, J. M., Brar, B. K., Arias, C. M., et al. (2005). A soluble mouse brain splice variant of type $2 \alpha$ corticotropin-releasing factor (CRF) receptor binds ligands and modulates their activity. Proc. Natl. Acad. Sci. U S A 102, 2620-2625. doi: 10.1073/pnas. 0409583102

Chen, P., Vaughan, J., Donaldson, C., Vale, W., and Li, C. (2010). Injection of Urocortin 3 into the ventromedial hypothalamus modulates feeding, blood glucose levels, and hypothalamic POMC gene expression but not the HPA axis. Am. J. Physiol. Endocrinol. Metab. 298, E337-E345. doi: 10.1152/ajpendo. 00402.2009

Cox, K. H., Deleon, D. V., Angerer, L. M., and Angerer, R. C. (1984). Detection of mRNAs in sea urchin embryos by in situ hybridization using asymmetric RNA probes. Dev. Biol. 101, 485-502. doi: 10.1016/0012-1606(84) 90162-3 
Deussing, J. M., Breu, J., Kühne, C., Kallnik, M., Bunck, M., Glasl, L., et al. (2010). Urocortin 3 modulates social discrimination abilities via corticotropin-releasing hormone receptor type 2. J. Neurosci. 30, 9103-9116. doi: 10.1523/jneurosci.1049-10.2010

Fekete, E. M., Inoue, K., Zhao, Y., Rivier, J. E., Vale, W. W., Szücs, A., et al. (2007). Delayed satiety-like actions and altered feeding microstructure by a selective type 2 corticotropin-releasing factor agonist in rats: intrahypothalamic urocortin 3 administration reduces food intake by prolonging the post-meal interval. Neuropsychopharmacology 32, 1052-1068. doi: 10.1038/sj. npp.1301214

Fragaszy, D., Visalberghi, E., and Fedigan, L. (2004). The Complete Capuchin: The Biology of the Genus Cebus. Cambridge: Cambridge University Press.

Gattass, R., Sousa, A. P., and Rosa, M. G. (1987). Visual topography of V1 in the Cebus monkey. J. Comp. Neurol. 259, 529-548. doi: 10.1002/cne.9025 90404

Hauger, R. L., Grigoriadis, D. E., Dallman, M. F., Plotsky, P. M., Vale, W. W., and Dautzenberg, F. M. (2003). International Union of Pharmacology. XXXVI. Current status of the nomenclature for receptors for corticotropin-releasing factor and their ligands. Pharmacol. Rev. 55, 21-26. doi: 10.1124/pr.55.1.3

Hoffman, G. E., Le, W. W., and Sita, L. V. (2008). The importance of titrating antibodies for immunocytochemical methods. Curr. Protoc. Neurosci. 45, 2.12.1-2.12.26. doi: 10.1002/0471142301.ns0212s45

Hsu, S. Y., and Hsueh, A. J. (2001). Human stresscopin and stresscopin-related peptide are selective ligands for the type 2 corticotropin-releasing hormone receptor. Nat. Med. 7, 605-611. doi: 10.1038/87936

Izar, P., Verderane, M. P., Peternelli-Dos-Santos, L., Mendonça-Furtado, O., Presotto, A., Tokuda, M., et al. (2012). Flexible and conservative features of social systems in tufted capuchin monkeys: comparing the socioecology of Sapajus libidinosus and Sapajus nigritus. Am. J. Primatol. 74, 315-331. doi: 10.1002/ajp.20968

Jamieson, P. M., Li, C., Kukura, C., Vaughan, J., and Vale, W. (2006). Urocortin 3 modulates the neuroendocrine stress response and is regulated in rat amygdala and hypothalamus by stress and glucocorticoids. Endocrinology 147, 4578-4588. doi: 10.1210/en.2006-0545

Kang, H. J., Adams, D. H., Simen, A., Simen, B. B., Rajkowska, G., Stockmeier, C. A., et al. (2007). Gene expression profiling in postmortem prefrontal cortex of major depressive disorder. J. Neurosci. 27, 13329-13340. doi: 10.1523/jneurosci.4083-07.2007

Kuperman, Y., and Chen, A. (2008). Urocortins: emerging metabolic and energy homeostasis perspectives. Trends Endocrinol. Metab. 19, 122-129. doi: 10.1016/j.tem.2007.12.002

Kuperman, Y., Issler, O., Regev, L., Musseri, I., Navon, I., Neufeld-Cohen, A., et al. (2010). Perifornical Urocortin-3 mediates the link between stress-induced anxiety and energy homeostasis. Proc. Natl. Acad. Sci. U S A 107, 8393-8398. doi: 10.1073/pnas.1003969107

Lewis, K., Li, C., Perrin, M., Blount, A., Kunitake, K., Donaldson, C., et al. (2001). Identification of urocortin III, an additional member of the corticotropin-releasing factor (CRF) family with high affinity for the CRF2 receptor. Proc. Natl. Acad. Sci. U S A 98, 7570-7575. doi: 10.1073/pnas. 121165198

Li, C., Chen, P., Vaughan, J., Lee, K.-F., and Vale, W. (2007). Urocortin 3 regulates glucose-stimulated insulin secretion and energy homeostasis. Proc. Natl. Acad. Sci. U S A 104, 4206-4211. doi: 10.1073/pnas.0611641104

Li, X., Fan, M., Shen, L., Cao, Y., Zhu, D., and Hong, Z. (2010). Excitatory responses of cardiovascular activities to urocortin 3 administration into the PVN of the rat. Auton. Neurosci. 154, 108-111. doi: 10.1016/j.autneu. 2009.12.004

Li, C., Vaughan, J., Sawchenko, P. E., and Vale, W. W. (2002). Urocortin III-immunoreactive projections in rat brain: partial overlap with sites of type 2 corticotrophin-releasing factor receptor expression. J. Neurosci. 22, 991-1001.

Lovenberg, T. W., Chalmers, D. T., Liu, C., and De Souza, E. B. (1995a). CRF2 $\alpha$ and CRF2 $\beta$ receptor mRNAs are differentially distributed between the rat central nervous system and peripheral tissues. Endocrinology 136, 4139-4142. doi: 10.1210/endo.136.9.7544278

Lovenberg, T. W., Liaw, C. W., Grigoriadis, D. E., Clevenger, W., Chalmers, D. T., De Souza, E. B., et al. (1995b). Cloning and characterization of a functionally distinct corticotropin-releasing factor receptor subtype from rat brain. Proc. Natl. Acad. Sci. U S A 92, 836-840. doi: 10.1073/pnas. 92.12.5759-b

Lynch Alfaro, J. W., Boubli, J. P., Olson, L. E., Di Fiore, A., Wilson, B., Gutiérrez-Espeleta, G. A., et al. (2012). Explosive Pleistocene range expansion leads to widespread Amazonian sympatry between robust and gracile capuchin monkeys. J. Biogeogr. 39, 272-288. doi: 10.1111/j.1365-2699. 2011.02609.x

Manocha, S. L., Shantha, T. R., and Bourne, G. H. (1968). A Stereotaxic Atlas of the Brain of the Cebus Monkey (Cebus Apella). London: Oxford University Press.

Paxinos, G., Huang, X. F., Petrides, M., and Toga, A. W. (2009). The Rhesus Monkey Brain-In Stereotaxic Coordinates. San Diego, CA: Elsevier.

Paxinos, G., Watson, C., Petrides, M., Rosa, M., and Tokuno, H. (2012). The Marmoset Brain in Stereotaxic Coordinates. London: Academic Press, Elsevier.

Pinato, L., Frazão, R., Cruz-Rizzolo, R., Cavalcante, J., and Nogueira, M. (2009). Immunocytochemical characterization of the pregeniculate nucleus and distribution of retinal and neuropeptide $\mathrm{Y}$ terminals in the suprachiasmatic nucleus of the Cebus monkey. J. Chem. Neuroanat. 37, 207-213. doi: 10.1016/j. jchemneu.2009.01.005

Reul, J. M., and Holsboer, F. (2002). Corticotropin-releasing factor receptors 1 and 2 in anxiety and depression. Curr. Opin. Pharmacol. 2, 23-33. doi: 10.1016/s1471-4892(01)00117-5

Reyes, T. M., Lewis, K., Perrin, M. H., Kunitake, K. S., Vaughan, J., Arias, C. A., et al. (2001). Urocortin II: a member of the corticotropin-releasing factor (CRF) neuropeptide family that is selectively bound by type 2 CRF receptors. Proc. Natl. Acad. Sci. U S A 98, 2843-2848. doi: 10.1073/pnas. 051626398

Sánchez, M. M., Young, L. J., Plotsky, P. M., and Insel, T. R. (1999). Autoradiographic and in situ hybridization localization of corticotropinreleasing factor 1 and 2 receptors in nonhuman primate brain. J. Comp. Neurol. 408, 365-377. doi: 10.1002/(SICI)1096-9861(19990607)408:3<365::AIDCNE5 $>3.0 . \mathrm{CO} ; 2-\mathrm{N}$

Sawchenko, P. E., Swanson, L. W., and Vale, W. W. (1984). Corticotropinreleasing factor: co-expression within distinct subsets of oxytocin-, vasopressin-, and neurotensin-immunoreactive neurons in the hypothalamus of the male rat. J. Neurosci. 4, 1118-1129.

Silva, J. D. S. Jr. (2001). Especiação nos Macacos-Prego e Caiararas, Gênero Cebus Erxleben, 1777 (Primates, Cebidae). Ph.D. Dissertation, Programa de Pós-Graduação em Genética, Universidade Federal do Rio de Janeiro, Rio de Janeiro.

Simmons, D. M., Arriza, J. L., and Swanson, L. W. (1989). A complete protocol for in situ hybridization of messenger RNAs in brain and other tissues with radio-labeled single-stranded RNA probes. J. Histotechnol. 12, 169-181. doi: 10.1179/014788889794651870

Singewald, G. M., Rjabokon, A., Singewald, N., and Ebner, K. (2011). The modulatory role of the lateral septum on neuroendocrine and behavioral stress responses. Neuropsychopharmacology 36, 793-804. doi: 10.1038/npp. 2010.213

Swanson, L. W., Sawchenko, P. E., Rivier, J., and Vale, W. W. (1983). Organization of ovine corticotropin-releasing factor immunoreactive cells and fibers in the rat brain: an immunohistochemical study. Neuroendocrinology 36, 165-186. doi: $10.1159 / 000123454$

Vale, W., Spiess, J., Rivier, C., and Rivier, J. (1981). Characterization of a 41-residue ovine hypothalamic peptide that stimulates secretion of corticotropin and $\beta$-endorphin. Science 213, 1394-1397. doi: 10.1126/science. 6267699

van der Meulen, T., Donaldson, C. J., Cáceres, E., Hunter, A. E., CowingZitron, C., Pound, L. D., et al. (2015). Urocortin3 mediates somatostatindependent negative feedback control of insulin secretion. Nat. Med. 21, 769-776. doi: 10.1038/nm.3872

van-Hover, C., and Li, C. (2015). Stress-activated afferent inputs into the anterior parvicellular part of the paraventricular nucleus of the hypothalamus: insights into urocortin 3 neuron activation. Brain Res. 1611, 29-43. doi: 10.1016/j. brainres.2015.03.009

Van Pett, K., Viau, V., Bittencourt, J. C., Chan, R. K., Li, H. Y., Arias, C., et al. (2000). Distribution of mRNAs encoding CRF receptors in brain and pituitary of rat and mouse. J. Comp. Neurol. 428, 191-212. doi: 10.1002/10969861(20001211)428:2<191::AID-CNE1>3.0.CO;2-U 
Vasconcelos, L. A., Donaldson, C., Sita, L. V., Casatti, C. A., Lotfi, C. F., Wang, L., et al. (2003). Urocortin in the central nervous system of a primate (Cebus apella): sequencing, immunohistochemical, and hybridization histochemical characterization. J. Comp. Neurol. 463, 157-175. doi: 10.1002/cne.10742

Vaughan, J., Donaldson, C., Bittencourt, J., Perrin, M. H., Lewis, K., Sutton, S., et al. (1995). Urocortin, a mammalian neuropeptide related to fish urotensin I and to corticotropin-releasing factor. Nature 378, 287-292. doi: 10.1038/378287a0

Venihaki, M., Sakihara, S., Subramanian, S., Dikkes, P., Weninger, S. C., Liapakis, G., et al. (2004). Urocortin III, a brain neuropeptide of the corticotropin-releasing hormone family: modulation by stress and attenuation of some anxiety-like behaviours. J. Neuroendocrinol. 16, 411-422. doi: 10.1111/j.1365-2826.2004.01170.x

Wittmann, G., Füzesi, T., Liposits, Z., Lechan, R. M., and Fekete, C. (2009). sDistribution and axonal projections of neurons coexpressing thyrotropinreleasing hormone and urocortin 3 in the rat brain. J. Comp. Neurol. 517, 825-840. doi: 10.1002/cne. 22180
Zmijewski, M. A., and Slominski, A. T. (2010). Emerging role of alternative splicing of CRF1 receptor in CRF signaling. Acta Biochim. Pol. $57,1-13$.

Conflict of Interest Statement: The authors declare that the research was conducted in the absence of any commercial or financial relationships that could be construed as a potential conflict of interest.

Copyright (c) 2017 Battagello, Diniz, Candido, da Silva, de Oliveira, Torres da Silva, Lotfi, de Oliveira, Sita, Casatti, Lovejoy and Bittencourt. This is an open-access article distributed under the terms of the Creative Commons Attribution License (CC BY). The use, distribution or reproduction in other forums is permitted, provided the original author(s) or licensor are credited and that the original publication in this journal is cited, in accordance with accepted academic practice. No use, distribution or reproduction is permitted which does not comply with these terms. 